Revista de Estudios Histórico-Jurídicos

[Sección Historia del Derecho Europeo]

XXXII (Valparaíso, Chile, 2010)

[pp. 281 - 308]

\title{
LA NORMATIVA SOBRE LOS PRISIONEROS Y LOS CAUTIVOS EN LA ESPAÑA CRISTIANA MEDIEVAL
}

[The Regulation on the Prisoners and the Captive Ones in the Christian Medieval Spain]

\author{
Francisco Javier Díaz GonZÁlez* \\ Universidad de Alcalá de Henares, España
}

\section{RESUMEN}

El presente trabajo trata de dar a conocer cuál era la regulación del trato que se daba a los cautivos y prisioneros en la España cristiana medieval, teniendo como base principal esta normativa los fueros municipales de la frontera y, a partir del siglo XIII, las Partidas de Alfonso X.

Palabras clave: Prisionero - Rescate - Botín.

\section{AbSTRACT}

This work attempts to make known what the regulation was regarding the treatment given to captive people and prisoners in Middle Age Christian Spain, using as main basis for this regulation the Fuero de La Frontera and, as from the $13^{\text {th }}$ century, the Partidas of Alfonso X.

KEYwORDS: Prisoner - Rescue - Bounty.

* Profesor titular en el Departamento de Fundamentos del Derecho y Derecho Penal de la Universidad de Alcalá. Dirección postal: Universidad de Alcalá, Departamento de Fundamentos del Derecho y Derecho Penal, 28801 Alcalá de Henares, Madrid, España. Correo electrónico: fjavier.diaz@uah.es 
La guerra en la España medieval era una de las más importantes fuentes de riqueza. Sin una frontera definida y en constante cambio, fueron continuas las cabalgadas y expediciones de castigo realizadas tanto por cristianos y musulmanes para la obtención de botín, destacando en este apartado la captura de prisioneros.

El tratamiento jurídico que se daba a estas actividades bélicas, en territorio cristiano, lo encontramos en esas normas jurídicas tan características de la España medieval que son los fueros municipales de las Extremaduras, que recogían por escrito los usos y las costumbres que se habían ido desarrollando a lo largo del tiempo. A ellos hay que añadir en la segunda mitad del siglo XIII la legislación de Alfonso X el Sabio, especialmente las Partidas ${ }^{1}$.

\section{El CAUTIVO MUSULMÁN EN LOS TEXTOS CRISTIANOS}

Los textos cristianos, a excepción de las Partidas, no hacen distinción entre prisionero y cautivo. Sin embargo, todos hacen referencia a un único enemigo común, el musulmán, el "moro", a quien se puede cautivar y, por ende, esclavizar. El texto llama "presos" a aquellos "que non resciben otro mal en sus cuerpos, si no es quanto en manera de aquella prision en que los tienen; o si lieuan alguna cosa dellos en razon de costa que ayan fecho, teniendolos presos; o por daño que ayan rescebido dellos, queriendo ende auer emienda. Pero con todo esso non les deuen matar luego adesora, despues que los touieren en su poder; ni darles pena, ni fazerles otra cosa, porque mueran. Fueras ende si fuessen presos por razon de justicia ${ }^{2}$. Por estas razones, los sabios antiguos non touieron por derecho... que el ome touiessen preso, que lo matassen, nin le diessen grand tormento, por que ouiesse de morir, ni lo pudiessen vender, ni seruirse del como de sieruo, ni deshonrrarle muger delante, nin apartassen a ella del, ni a los fijos para venderlos, partiendolos vnos de otros" ${ }^{3}$. Es decir, que el preso, que podemos calificar como "prisionero de guerra", disfruta de una serie de garantías que protegen su persona y la de sus familiares, pero, ¿todo tipo de presos las disfruta? La propia norma nos dice que no, pues añade que solo se entiende de "los presos de vna Ley, assi como quando fuesse guerra entre Christianos". Por tanto, el enemigo por excelencia, el musulmán, el "moro", el “infiel”, está excluido de esas garantías.

Aunque las Partidas hacen esta distinción, no la encontramos en el Derecho romano justinianeo, por más que el autor haga esa afirmación sobre los "sabios antiguos”. El Derecho canónico, como se desprende del Decreto de Graciano ${ }^{4}$,

\footnotetext{
${ }^{1}$ Sobre la influencia del Derecho romano en la regulación del estatuto del cautivo en las Partidas, véase mi artículo La base jurídica romana en la regulación del cautivo en las Partidas, en Revista General de Derecho Romano, 14 (2010), pp. 1-27.

${ }^{2}$ Partida II,29,1 [edición usada: Las siete partidas del Sabio Rey don Alonso el Nono; nuevamente glosadas por Gregorio López (Madrid, BOE, 1973)].

${ }^{3}$ Ibíd.

${ }^{4}$ C. 23, c. 3, q. 1: "In bellicis armis multi Deo placere possunt. Item eiusdem ad Bonifatium. [epist. CCVII.] Noli existimare, neminem Deo placere posse, qui armis bellicis ministrat. In his erat sanctus Dauid, cui Dominus tam magnum perhibuit testimonium. In his etiam plurimi illius temporis iusti. In his erat ille centurio, qui Domino dixit: 'Non sum dignus, ut intres sub
} 
aconseja el buen trato a los prisioneros. Sin embargo, como afirmó siglos más tarde Gregorio López en su glosa a las Partidas, la distinción entre prisionero y cautivo era debido a la costumbre general de la época, no recogida en el Derecho común ${ }^{5}$.

Hay casos en Partidas en el que se puede capturar y esclavizar a un cristiano: "Malos Christianos y ha algunos, que dan ayuda, o consejo a los Moros, que son enemigos de la Fe; assi como quando les dan, o les venden armas de fuste, o de fierro, o galera, o naues fechas, o madera para fazellas. E otrosi, los que guian o gouiernan los nauios dellos, para fazer mal a los Christianos. E otrossi, los que les dan, o les venden madera, para fazer algaradas, o otros engeños. E porque estos fazen grand enemiga, touo por bien Santa Eglesia, que qualesquier que prendiessen a algunos de los que estas cosas fiziessen, que los metiessen en seruidumbre, e los vendiessen, si quisiessen, o se siruiessen dellos, bien así como de sus sieruos. E demas desto, son descomulgados estos atales, tan solamente por el fecho, segund dize en el Titulo de las descomulgaciones: $e$ deuen perder todo quanto que ouieren, e ser del Rey"6. Este precepto, así como otros sobre el mismo asunto que podemos encontrar en varias leyes de las mismas Partidas $^{7}$, toma como referencia a otras normas de Derecho común, tanto canó-

tectum meum'. 1. Hoc ergo primum cogita, quando armaris ad pugnam, quia uirtus tua etiam ipsa corporalis donum Dei est. Sic enim cogitabis de dono Dei non facere contra Dominum. Fides enim, quando promittitur, etiam hosti seruanda est, contra quem bellum geritur; quanto magis amico, pro quo pugnatur? Pacem habere uoluntatis, bellum autem debet esse necessitatis, ut liberet Deus a necessitate, et conseruet in pace. Non enim pax queritur, ut bellum exerceatur, sed bellum geritur, ut pax acquiratur. Esto ergo bellando pacificus, ut eos, quos expugnas, ad pacis utilitatem uincendo perducas. 'Beati enim pacifici' (ait Dominus) 'quoniam filii Dei uocabuntur'. Si autem pax humana tam dulcis est pro temporali salute mortalium, quanto dulcior est pax diuina pro eterna salute angelorum? Itaque hostem pugnantem necessitas deprimat, non uoluntas. Sicut bellanti et resistenti uiolentia redditur, ita uictoriis capto misericordia iam debetur, maxime in quo pacis perturbatio non timetur [edición usada: Corpus iuris canonici, Decretum Magistri Gratiani (Graz, 1955)].

${ }^{5}$ Nota 1 a la Partida II,29,1: "Alguna cosa. Tene menti istam legem, nam de iure communi nulla lege cavetur, quem effectum haber ista captio personarum in bello inter Reges Christianos, et condictor huius legis habuit respectum ad generalem consuetudinem, secundum quam Christiani capti in talibus bellis possunt detineri in carcere pro talea habenda [...]”.

${ }^{6}$ Partida IV,21,4.

${ }^{7}$ Partida I,9,31: "Falsos Christianos Ilama Santa Eglesia, a todos aquellos que dan ayuda, o consejo en alguna manera, a los enemigos de la Fe contra los Christianos; e avn a todos aquellos que les dan, o venden armas, o Nauios, o Galeon, o madera para ellos; e otrosi a los que la lleuan. E tan gran falsedad tiene Santa Eglesia que fazen, los que ayudan en alguna destas maneras sobredichas, o en otra semejante dellas; que por tal fecho solamente los da por descomulgados de la mayor descomunion, assi como sobredicho es, maguer non los descomulgassen concejeramente. E manda que todos sus bienes destos atales, que los tomen luego que alguna destas cosas fizieren, los Señores de aquella tierra donde fueren moradores: e otorga demas desto, que quienquier que los prenda, que sean sus sieruos, e que los puedan vender, e seruirse dellos, tambien como si fuessen Moros. E si por auentura acaesciesse, que alguno se fuesse para ellos, para ayudarles contra los Christianos, o diessen ayuda, o consejo a otros, que lo fiziessen; manda que quantos tan grande enemiga como esta fizieren, que non los sotierren nunca jamas en las sepulturas de la Eglesia, si ante que muriessen non fiziessen gran enmienda ende a Dios, e a su Señor natural, contar quien les dieron aquella ayuda. E si acaesciesse que algunos soterrasen y, manda el derecho, que les saquen dende los huesos muy deshonrradamente, como de ome que fizo tran grande traycion contra Dios, 
nicas $^{8}$, como romanas ${ }^{9}$, pero no sigue las consecuencias jurídicas de éstas últimas, pues castigan el comercio de géneros de guerra con los bárbaros con la muerte.

e contra sus Christianos, a quien deue ayudar, e non fazer estoruo. E como quier que estos atales non tan solamente por el fecho, o por el consejo que dieron a los enemigos de la Fe, sean descomulgados; mas manda Santa Eglesia, que todos los Domingos, e fiestas, los denuncien concejeramente por descomulgados ante los fieles Christianos"; Partida V,5,22: "Arma de fuste, nin de fierro non deuen vender, nin prestar los Christianos a los Moros, nin a los otros enemigos de la Fe. Otrosi defendemos, que ninguno de nuestro Señorio non les lleue a la su tierra, mientra guerrearen con nusco, trigo, nin ceuada, nin centeno, nin olio, nin ninguna de las otras cosas, e viandas con que se pudiessen amparar, ni gelo vendan, nin gelo den en nuestro Señorio, para lleuar a su tierra. Pero por bien tenemos, que los que vinieren a nuestra Corte en mensajeria, o con pleyto, que les vendan la vianda, que ouieren menester para comer, o para bever, demientra que y moraren. Esi alguno contra esto fiziere, mandamos, que pierda porende todo lo que ouiere, e que este su cuerpo a merzed del Rey. Ca dar armas, o fazer otra ayuda a los enemigos de la Fe, con que se puedan amparar, es vna maera como de traycion".

${ }^{8} \mathrm{X}$. 5,6,6: "Ita quorundam animos occupavit saeva cupiditas, ut, qui gloriantur nomine Christiano Sarracenis arma, ferrum et ligamina deferant galearum, et pares aut etiam superiores in malitia fiant illis, dum ad impugnandos Christianos arma eis et necessaria subministrant. Sunt etiam, qui pro cupiditate sua in galeis et piraticis Sarracenorum navibus regimen et curam gubernationis exerceant. Tales igitur, ab ecclesiastica communione praecisos, et excommunicationi pro sua iniquitate subiectos, et rerum suarum per principes [saeculi] catholicos et consules civitatum privatione mulctari, et capientium fieri servos, si capti fuerint, censemus. Praecipimus etiam, ut per ecclesias maritimarum urbium crebra et solennis in eos excommunicatio proferatur. Excommunicationis quoque etc." [en Corpus Iuris Canonici, Decretalium Collectiones (Graz, 1955)]; X, 5,6,12: "Quod olim praeceptum fuit (Et infra:) Sane, licet hoc fuerit in concilio Lateranensi districte inhibitum, nos tamen de consilio fratrum nostrorum omnes illos excommunicationi supponimus, qui iam amplius cum Sarracenis mercimonium habuerint, vel per se vel per alios navibus, seu quocunque alio ingenio, eis aliqua rerum subsidia seu consilia, quamdiu inter nos et illos guerra duraverit, duxerint impendenda. Vestrae igitur discretioni mandamus atque districte praecipimus, quatenus nec per vos, nec per vestras naves, nec alio quocunque modo aut ingenio, eis mercimonia, consilia vel alia subsidia transmittatis, ne, si forte aliqui in sua malitia indurati secus agere praesumpserint, non solum ipso iure incidant in excommunicationem illam, verum etiam illi iram Dei viventis incurrant"; X, 5,6,17: "Ad liberandam terram sanctam (Et infra:) Excommunicamus praeterea et anathematizamus illos falsos et impios Christianos, qui contra ipsum Christum et populum Christianum Sarracenis arma, ferrum et ligamina deferunt galearum; eos etiam, qui galeas eis vendunt vel naves, quique in piraticis Sarracenorum navibus curam gubernationis exercent, vel in machinis aut quibuslibet aliis aliquod eis impendunt consilium vel auxilium in dispendium terrae sanctae; ipsosque rerum suarum privatione mulctari, et capientium servos fore censemus, praecipientes, ut per omnes urbes maritimas diebus dominicis et festivis huiusmodi sententia publice innovetur. Et talibus gremium non aperiatur ecclesiae, nisi totum, quod ex commercio tam damnato perceperint, et tantundem de suo in subsidium terrae sanctae transmiserint, ut aequo iudicio in quo deliquerint puniantur. Quodsi forte solvendo non fuerint, sic alias reatus talium castigetur, quod in poena ipsorum aliis interdicatur audacia similia praesumendi".

${ }^{9}$ CI., 4,41,2: "Imperator Marcianus a Constantino pp.: Nemo alienigenis barbaris cuiuscumque gentis ad hanc urbem sacratissimam sub legationis specie vel sub quocumque alio colore venientibus aut in diversis aliis civitatibus vel locis loricas et scuta et arcus sagittas et spathas et gladios vel alterius cuiuscumque generis arma audeat venumdare, nulla prorsus isdem tela, nibil penitus ferri vel facti iam vel adhuc infecti ab aliquo distrahatur. Perniciosum namque romano imperio et proditioni proximum est barbaros, quos indigere convenit, telis eos, ut validiores reddantur, instruere. 1. Si quis autem aliquid armorum genus quarumcumque nationum barbaris alienigenis contra pietatis nostrae interdicta ubicumque vendiderit, bona eius universa proscribi 
Los fueros, en cambio, como el de Teruel, establecen una importante multa (100 maravedís) al que llevare armas a tierra de moros, o, si no pudiera pagarla, sea enforcado ${ }^{10}$, mientras que el de Cuenca y otros de su grupo establecen que el acusado sea despeñado, si se puede probar; pero sí no, "sálvese con doce vecinos y sea creido; o jure él solo y responda al reto, lo que más le plazca al Concejo" ${ }^{11}$. El Fuero de Plasencia, finalmente, ordena lo siguiente: "Todo omne que armas o cauallo ho yegua ho ningun conducho a tierra de moros leuare a uender, enforquenle ho peche .C. morauedis e el qui lo fallare leuando, prendalo por suyo, si se pudiere prouar; si non, saluesse con tres uezinos. Et qui lo firiere ho matare a aquel fallare, peche la calonna doblada, e quanto fuere preso, luego sea tornado a Plazencia; si non, peche aquel commo por ladroniço"12.

Sin embargo, en el Derecho territorial catalán estaba permitida la venta de armas a los sarracenos, siempre y cuando se contase con el consentimiento del príncipe, pues en caso contrario, debían recuperarlas los vendedores, y si no fuera posible, pagar una multa de 100 onzas de oro ${ }^{13}$.

También podía cautivarse al cristiano que luchara contra los de su fe apoyando a los musulmanes ${ }^{14}$.

Los cautivos "son llamados por derecho, aquellos que caen en prision de omes de otra creencia”, y por lo cual se tiene un poder omnímodo sobre ellos, pues se les puede matar, "por desprecio que non ha su Ley, torturar cruelmente o esclavizarles, metiendolos a tales seruicios, que querrían ante la muerte, que la vida”. Además, la cautividad conlleva graves desgracias personales como la venta del cautivo a un tercero, la separación forzosa del marido de la mujer, de los hijos de los padres y de las madres, de hermanos o de otros parientes y también de los amigos, "que es muy fuerte cosa departir a vnos de otros: ca bien como el ayuntamiento del amor passa, e vence al linaje, e a todas las otras cosas; assi es mayor la cuyta, e el pesar quando

protinus ac fisco addici, ipsum quoque capitalem poenam subire decernimus" (a. 455-457) [en Corpus Iuris Civilis, Codex Iustinianus (Berlin, 1906)].

${ }^{10}$ Fuero de Teruel, capítulo 526 (ed. de Max Gorosch, Estocolmo, 1950).

${ }^{11}$ Fuero de Cuenca, capítulo XIII, 4 (ed. de A. Valmaña Vicente, Cuenca, 1978).

${ }^{12}$ Fuero de Plasencia, capítulo 153 [ed. de M. J. Postigo Aldeamil, en Revista de Filología Románica, 2 (1984), pp. 175-214].

${ }^{13}$ Usatge 123 [en Los Usatges de Barcelona, ed. de F. Valls Taberner (Barcelona, 1984)]: "Christiani non vendant arma sarracenis, nisi ex consensu principis; quod si fecerint, arma que ven [di]derint recuperent, quamvis eis grave sit, et nisi hoc fecerint, centum uncias auri potestati persolvant. Similiter componant si cibum eis vendiderint contradicente principe. Eandem composicionem faciat qui fecerit scire sarracenis cavalcadas vel ardimentum potestatis, vel discoperiet eum de consilio suo vel de secretis suis, emendato malo quod inde exierit".

${ }^{14}$ Partida III,28,20: "Las cosas de los enemigos de la Fe, con quien ni ha Tregua, nin Paz el Rey, quien quier que las gane, deuen ser suyas; fueras ende Villa, o Castillo. Ca maguer alguno la ganasse, en saluo fincaría el señorio della al Rey, en cuya conquista lo gano. Empero deuele fazer el Rey señalada honrra, e bien, al que la ganasse. Otrosi dezimos, que quien quier que prenda ome en tiempo de guerra, que este en la tierra de los enemigos, e faga la guerra a los Christianos, que sea su catiuo de aquel qui lo prisiere, quier sea Christiano, quier Moro; más luego que saliesse del poder de aquel que lo catiuasse, o tornasse a la tierra de los enemigos, perdería el señorio del, el que lo ouiesse catiuado, o el que lo comprasse del; e sería por ende libre". 
se parten". Por todo ello, según las Partidas, la cautividad es una de las peores situaciones en las que puede caer una persona ${ }^{15}$.

Los musulmanes capturados en las expediciones bélicas por parte de los cristianos hispánicos eran un elemento más del botín, que posteriormente se vendería en almoneda pública y se repartiría los beneficios obtenidos. En los Furs de Valencia se establece la obligación de resarcir al comprador en caso de ocultación de enfermedad o defecto físico del cautivo ${ }^{16}$.

Pero en ocasiones la normativa permitía que algunos cautivos no formaran parte de la masa del botín. En primer lugar se tenía en cuenta la posición social del cautivo, como el Fuero de Calatayud o el de Daroca, que establecen que si el cautivo es rey debe ser entregado al monarca ${ }^{17}$; en los textos de la familia del Fuero de Cuenca, si el moro fuese un alcaide o un señor y el monarca lo deseaba tener, debía pagar la cantidad de $100 \mathrm{mrs} .^{18}$; en el fuero de Guadalajara de 1133 se debían pagar cien sueldos ${ }^{19}$; el Fuero de Viguera y Val de Funes, en Navarra, reconoce a los "ricos hombres" que tienen tierras por el rey o que van en su compañía a la guerra, el privilegio de recibir del rey $100 \mathrm{mrs}$. por capturar un prisionero musulmán cuyo valor fuera de más de $1.000^{20}$; en el Fuero de las Cabalgadas, realizado en época de Alfonso X, las personas del rey moro o su hijo o aquel que valiese más de mil maravedís de oro o fuese alcaide de una fortaleza, establece que el rey puede pagar su rescate a los captores ${ }^{21}$; el Espéculo sigue el mismo criterio del fuero de Cuenca, pero haciendo mención al rey moro o a sus

\footnotetext{
${ }^{15}$ Partida II, 29,1.
}

${ }^{16}$ Furs de Valencia, IX,17,9 [ed. de G. Colón y A. García (Barcelona, 1980-1999)]: "Si alcú vendrà servu en encant o en altre loch, o sarrahí o sarrahina, o cavall o rocí, o mul o ase o bou, o qualque altra bèstia, lo venedor no sia tengut de vici o de malaltia al comprador, si aquell vici o aquella malaltia porà manifestament apparer al comprador. Mas de malaltia o de vici que no apparrà, sia tengut lo venedor al comprador, si aquella malaltia o aquell vici era en aquella cosa venunda enans que la compra o la venda fos feita, de la qual malaltia o del qual vici qui no apparrà lo venedor, jasia ço que no sabrà aquella malaltia o aquell vici qui no és apparexent, sia tengut al comprador en aytant quant ell la comprarà meyns si sabés que aquella malaltia o aquell vici fos. Emperò, si.l venedor sabrà la malaltia o.l vici, sia tengut al comprador de retre tot lo preu $e$ tot lo seu interesse, e que recobre la cosa viciosa o malalta que haurà venuda. Vici amagat és appellat bèstia que ha costum o abte de tornar a enrere, o que es repròpria o servu o serva que cau de gota, o que ha menaho perdurable, o que ha sanch fluix, o qui és mut o sort o altres semblants vicis amagats. Vici aparexent és appellat quant és geperut o quant li aparexen los senyals de leges nafres ue ha haüdes, o quant ha nafres que encara no són sanades, o quant se dol o és contret o és cech o laganyós, o quant haurà perdut la mà o altre membre, o serà lebròs o ronyós, o altres semblants vicis que manifestament aparexen".

${ }^{17}$ Fuero de Calatayud, capítulo 13 [ed. de J. I. Algora Hernando y F. Arranz Sacristán (Zaragoza, 1982)]; Fuero de Daroca (ed. de M. del M. Agudo Romeo, Zaragoza, 1992).

${ }^{18}$ Fuero de Cuenca, capítulo XXX,34; Fuero de Teruel, capítulo 590.

${ }^{19}$ Fuero de Guadalajara de 1133, en Muñoz y Romero, T., Colección de Fueros Municipales y Cartas Pueblas de los reinos de Castilla, León, Corona de Aragón y Navarra (Madrid, 1847), p. 510.

${ }^{20}$ Fuero de Viguera y Val de Funes, capítulo 187 (ed. de J. M. Ramos y Loscertales, Salamanca, 1956].

${ }^{21}$ Fuero de las Cabalgadas, títulos XXXIV y LXXXIII, en Memorial Histórico Español (Madrid, 1851), II. 
familiares, debiendo ser destinados los 100 mrs. pagados por el rey al botín y después de ello sacar el quinto que le corresponde a aquel ${ }^{22}$; las Partidas, por su parte, reconocen el privilegio real de apoderarse del jefe del ejército enemigo que fuese hecho prisionero, así como de sus mujeres, sus hijos, y demás personas que estuviesen a su servicio ${ }^{23}$; también se reconoce el derecho del rey, tras pagar los $100 \mathrm{mrs}$. de rigor, sobre toda persona que vendida en la almoneda su precio fuera superior a $1.000 \mathrm{mrs} .{ }^{24}$. Estas prerrogativas del monarca sobre determinados prisioneros no sólo le corresponden, según las Partidas, cuando se encuentra presente en el campo de batalla, sino cuando se producen otras acciones bélicas "menores" y no participa en ellas, como "fazienda, lid, caualgada, torneo, espolonada, algara, celada, asalto a una villa o a un castillo, por fuerça o por furto, o a navíos enemigos, por mar o por tierra, o en otra manera qualquier que pudiesse ser de guerra" 25 . En estas ocasiones, el rey puede entregar esta parte del botín, siempre que lo indique señaladamente, al caudillo mayor que fuese en su lugar ${ }^{26}$.

Si se capturase al jefe de una expedición de saqueo, un adalid musulmán, la suerte de éste estaba echada. Se abonaría al captor, según el Fuero de Cuenca, 10 maravedís y quedaría a disposición del concejo de la ciudad darle muerte de la forma que mejor placiera ${ }^{27}$

Otros prisioneros que no se incluían en la almoneda, como reconocían las Partidas, eran aquellos que eran utilizados para intercambiarlos por cautivos capturados por el enemigo. El intercambio podía realizarse durante la expedición como reconocían y permitían el Fuero de Uclés ${ }^{28}$ o el Fuero de las Cabalgadas ${ }^{29}$.

Una vez finalizada la cabalgada, se podían seleccionar los moros que iban a ser destinados al intercambio por prisioneros cristianos, no debiéndose entregar por ellos a la hacienda real el quinto u otro derecho correspondiente ${ }^{30}$. El Fuero de las Cabalgadas permitía el intercambio de los prisioneros capturados, siempre y cuando tuvieran la misma condición ("que si el cativo cavallero fuere et cavallero cativo y oviere, porque aquell puedan aver, sea dado por ell. Et otrosi peón por peón

\footnotetext{
${ }^{22}$ Espéculo, III,7,1 (ed. de la Real Academia de la Historia, Madrid, 1836).

${ }^{23}$ Partida II,XXVI,5.

${ }^{24}$ Ibíd.

${ }^{25}$ Ibíd.

${ }^{26}$ Ibíd.
}

${ }^{27}$ Fuero de Cuenca, capítulo XXXI,18 y 19. El Fuero de Teruel establece en el capítulo 625 la recompensa de 100 sueldos a quien trajese la cabeza del adalid, no diciendo nada para el que lo capturase vivo, eso sí, coincide con el de Cuenca en el fin reservado al musulmán.

${ }^{28}$ Fuero de Uclés, capítulo 157: "Totus homo qui in fonsado fuerit et captivaret, dent ei unum maurum communal" [ed. de F. Fita, en Boletín de la Real Academia de la Historia, 14 (abril 1889), pp. 302-355)].

${ }^{29}$ Fuero de las Cabalgadas, tít. LI: "Manda el Emperador que si algunos cavalgadores de cavallo o de pie andaren en una companya et cativaren dellos andando en la cavalgada que faran, den parte a aquellos que seran cativos tan bien como a uno nin a otro".

${ }^{30}$ Partida II,26,8: "[...] Otrosí, quando acaesciesse que alguno catiuassen en qual manera quier de guerra, e los otros de la caualgada diessen por él algund catiuo, de los que ellos traxessen pressos, o dineros para comprarlo; de tal catiuo, nin de los marauedis quel diessen, de que lo comprassen, non deuen dar al Rey, quinto, nin diezmo, nin otro derecho alguno [...]". 
cativo") ${ }^{31}$. Tanto la exención del quinto como el intercambio de prisioneros de la misma condición son recogidos en los fueros de la familia del de $\mathrm{Cuenca}^{32}$ y en el Espéculo ${ }^{33}$.

No sólo los guerreros moros capturados en las expediciones bélicas servían para intercambiarlos por prisioneros cristianos. La legislación medieval permitía la adquisición en territorio cristiano de cautivos musulmanes para realizar con ellos el intercambio. El Fuero de Cuenca ordenaba que: "Cualquiera que compre un moro en Cuenca por el que quieran dar a cambio un cautivo cristiano, el dueño del moro reciba el precio que le costó, más diez maravedis de ganancia, y entréguelo; después que el moro sea testificado, si es vendido o malvendido, el dueño del moro saque al cristiano de la cautividad tras recibir el precio citado más arriba" ${ }^{34}$. El mismo criterio sigue el Fuero Extenso de Sepúlveda ${ }^{35}$ y el de Teruel ${ }^{36}$.

En el Fuero de Escalona se ordena que el que tenga un cautivo moro debe cederlo contra reembolso de su valor aumentado en un tercio para el rescate de un cristiano ${ }^{37}$.

El Fuero de Alba de Tormes establece un curioso sistema da datación del valor del musulmán destinado a ser canjeado. Se manda en primer lugar que

\footnotetext{
${ }^{31}$ Fuero de las Cabalgadas, tít. LXXXIII.

${ }^{32}$ Fuero de Cuenca, capítulo XXX,21: "Tanto los caballeros como los de a pie no den por fuero la quinta parte del moro que entreguen por cautivo. Ni tampoco han de dar la quinta parte, ni la sexta, ni la séptima de las demás cosas, sino tan solamente de los moros, de las bestias, de los ganados ovinos y vacunos". El Fuero de Teruel, en cambio, solamente se refiere al a exención del quinto (capítulo 583). En lo referente al intercambio de prisioneros de la misma condición, se establece en el Fuero de Cuenca que: "Si un caballero o uno de a pie de la hueste es hecho prisionero, sus armas y su cabalgadura sean indemnizadas" (capítulo XXX,32); y "Si un caballero resulta cautivo y en la hueste hay un caballero moro por el que se pueda canjear, entréguese a cambio. Cámbiese igualmente un moro de a pie por un cristiano de a pie" (capítulo XXX,33). En el mismo sentido, el Fuero de Teruel (capítulo 589).

${ }^{33}$ Espéculo, III,7,11: “[...] E por ende dezimos que si alguno de los que van en cavalgada o en otra guerra cativase, debe dar la cavalgada otro por él de los que ellos cativasen, segunt qual ome fuere cavallero o peon. Esi no cativasen ninguno que pudiesen dar por él, denle otro tanto de la cavalgada de que conpre otro de la guisa que dixiemos en ayuda que de por si. E de tal cativo, nin de los mrs. que dieren para conprarle, non deven dar quinto, nin sesmo, nin diezmo, nin otro derecho ninguno [...]".

${ }^{34}$ Fuero de Cuenca, capítulo I,23.

${ }^{35}$ Fuero romanceado de Sepúlveda, capítulo 20 (en Los Fueros de Sepúlveda, ed. de E. Sáez, Segovia, 1953): “Otrossí, mando que qui comprare moro por que dieran dar christiano cativo, den al sennor del moro el precio quel costó et X mrs. de ganancia, e del moro; e si después que el moro fuere testiguado, lo vendieren o lo malmetieren, el sennor del moro saque el christiano, dándol el precio, assi como sobredicho es"

${ }^{36}$ Fuero de Teruel, capítulo 521: "Mando encara que qualquiere que moro conprare por el qual catiuo cristiano querrán dar, el sennor del moro prenga el precio que'l costó et de ganancia $X$ morauedis alfonsis et dé el moro, como es fuero. Si por auentura, después que el moro fuere testiguado, el sennor lo uendiere o por alguna manera lo malmetiere, el sennor del moro saque el cristiano de catiuo, recibiendo el precio sobre dicho".

${ }^{37}$ Fuero de Escalona, capítulo 29 [ed. de A. Garcia-Gallo, Los Fueros de Toledo, en Anuario de Historia del Derecho Español, 45 (1975), pp. 464-467], "Si quis autem tenuerit mauro captivo in quantum comparatum fuerit, terciam partem dessuper accipiat, et mauro supra nominato pro christiano tribuat".
} 
se pague lo que costó más la mitad, debiendo probarse ese precio si se estima necesario con tres testigos. Si el musulmán fuese ganado en cabalgada o en fonsado, el precio sería de 30 maravedís si no fuese de mierce, es decir, que está apalabrada su venta al alfaqueque, pero si lo fuese, entonces su valor será más de 30 maravedís; para probar esta condición, el dueño del esclavo deberá presentar tres testigos. Si juran a favor, la cantidad a pagar será de 50 maravedís, pero si no, será de 30. Si el dueño del moro no creyese que iba a ser utilizado para liberar a un cautivo cristiano, estando éste en esa situación por la prisión del musulmán, entonces deberá enseñársele una carta señalada de éste último que lo demuestre, pagándosele después 50 o 30 maravedís según sea el cautivo musulmán de mierce o no. Sí aún así no entregase al cautivo musulmán, será multado por el concejo con 100 maravedís ${ }^{38}$.

El Fuero de Plasencia también recoge la figura de la compra de un cautivo musulmán para intercambiarlo por un cristiano prisionero. El comprador debería abonar al dueño del prisionero lo que éste costó en la almoneda más la mitad. Sin embargo, si el musulmán comprado en la almoneda fuese donado al señor de Plasencia o al obispo o a los freires calatravos o a otro habitante de la villa, se pagarían 30 o 15 maravedís, respectivamente, si la condición del cautivo cristiano fuera de caballero o de peón. En el caso de que la compra fuera realizada fuera de la almoneda, el Fuero de Plasencia ordena que se apliquen los precios establecidos en los casos de donación ${ }^{39}$. En un plazo de 30 días, una vez convenido con el alfaqueque, el moro o la mora deberán entregar lo que costaron, mientras que el cristiano liberado deberá abonar la ganancia en un plazo de nueve días desde que retornó. Pero, si en un plazo de cuatro meses no llegase el cristiano "sea la uoluntat

${ }^{38}$ Fuero de Alba de Tormes, capítulo 91 (edición de P. Carrasco - I. Carrasco, Estudio léxicosemántico de los fueros leoneses de Zamora, Salamanca, Ledesma y Alba de Tormes. Concordancias lematizadas (Granada, 1997)), dos volúmenes]: "Todo omne o muler de Alba o de su termino que moro o mora ouiere, e omne o muler de Alba o de su termino por el loguiere en catiuo, silo compro, denle por el tanto e medio; e hi luego diga quanto costo, e si non gelo crouieren, iure con III. uezinos posteros, e denle tanto e medio. Esi dixiere donno de moro o de mora: "non lo compre mas ganelo en caualgada o en fonssado", si non fuere de mierce, denle por el.XXX. morauedis. Esi dixiere donno de moro que de mierce es o destaxado a de.XXX. morauedis a arriba, e el pariente del catiuo o dela catiua non gelo crouieren, iure donno de moro o de mora con.III. uezinos que de mierce era, o destayado auie de.XXX. morauedis arriba; si iurare, denle por el .I. morauedis; e si non iurar, denle. $X X X$. morauedis. E si dixiere dono de moro o de mora: "non te lo creo que tu pariente o tu parienta por mio moro o por mia mora iaze en catiuo", el pariente del catiuo o dela catiua de tal carta sennalada del moro o dela mora que sea creedera; e si tal carta diere, $e$ non fuere de mierce, del.XXX. morauedis por el; e si fuere de mierce, del.L. morauedis por el; e si donno de moro o de mora non lo quisiere dar olo traspusiere, peche .C. morauedis e delo. E por esto el demandador ni el amparador non se alce ala real potestat".

${ }^{39}$ Fuero de Plasencia, capítulo 22: "En el XX'IIo logar otorgo que todo omne, cristianos o iudios, que en almoneda de Plazencia moro o mora compre e por él cristiano catiuo dar quisiere, dé el precio que costó e la meetat del pecio de la primera almoneda. Et el sennor de la uilla, e el obispo e los fradres cogullados esten firmes en este fuero en Plazençia. Et por aquel qui dado fuere donado, si quier a su sennor, si quier a obispo o a frades o a todos los otros que de Plazencia o de su termino fueren, por caualero de.XXX. morauedis, por peon. $X V$., todauia su pariente sacando. Todos los otros moros que falados fueren o uendidos en Plazencia o en su termino sin almoneda, tal fueron ayan como los donados [...]". 
del sennor del moro, recebiendo moro o mora o ssu auer, retornando el auer que tiene por él. Et a estos plazos por quanto non pagare, doblado lo dê", entregándolo en el corral de alcaldes ${ }^{40}$. Si el moro o la mora muriesen mientras se espera la vuelta del cristiano "del cabdal, si fuere, dé todo el cabdal e la ganancia" "11. Finalmente, si una vez apalabrado el precio, el musulmán es vendido o malvendido, el dueño saque al cristiano de la cautividad tras recibir el precio citado más arriba ${ }^{42}$.

En Navarra, el texto de Viguera y Val de Funes permite que si algún cristiano fuese hecho cautivo por los moros y en la villa se hallase un prisionero musulmán por el que se solicita su liberación, se compraría a su propietario por la suma de 120 sueldos y sería intercambiado por el vecino prisionero ${ }^{43}$.

Los fueros aragoneses establecen otros criterios en cuanto a la compra del cautivo moro para intercambiarlo por el cristiano. Así, el Fuero de Calatayud sólo ordena que se pague lo que costó la compra del moro ${ }^{44}$; en el de Daroca, sin embargo, los padres del cautivo abonarían lo que le costó al dueño comprarlo en la almoneda, su alimentación y 12 dineros por el "carcelaje” o derecho de custodia que se paga al magistrado por guardar al moro ${ }^{45}$.

Tampoco formaban parte del botín los cautivos destinados a recompensar méritos de guerra. Así, aquel que entrase primero en una fortaleza tenía derecho a uno de los musulmanes que allí se hallasen, y si fueran dos o más los que entrasen a la vez, el prisionero era tenido en común ${ }^{46}$.

Por último, no formaban parte del botín los musulmanes hechos prisioneros por sus hermanos de fe y que fuesen abandonados mientras un apellido cristiano persigue a los invasores. Se establece la obligación de dejarles libres, con la condición de que no vuelvan con sus captores ${ }^{47}$

${ }^{40}$ Ibíd.

${ }^{41}$ Ibíd.

42 Ibíd.

${ }^{43}$ Fuero de Viguera y Val de Funes, capítulo 9: “[...] Otrosí, si alguno cayere en captivo e omne de la villa touiere moro captiuo et demandaren aquel moro por quoalquiere, tómenle a su vezino et dénle por el captiuo christiano et dénlo a su seynnor del moro CXX ss.".

${ }^{44}$ Fuero de Calatayud, capítulo 46: "El que tenga a un moro cautivo en Calatayud y por ese moro tiene alguien un cristiano en tierras de moro, vengan los parientes del cristiano y paguen por él el mismo precio por el que fue comprado el moro, y después de que lo hayan hecho, llévense al moro y traigánse a su cristiano; si no saliera después a recatarlo, el cristiano que era dueño del moro, si le parece, recoja a su moro y recupere el precio que pagó".

${ }^{45}$ Fuero de Daroca, capítulo 47: "Si algún vecino de Daroca está cautivo en tierra de paganos y otro vecino tiene algún cautivo sarraceno en Daroca, a cambio del cual el cristiano pueda salir libre, los padres del cautivo entreguen al dueño del sarraceno tanto cuanto le costó en la almoneda y su alimentación y XII dineros por el carcelaje y entréguenlo en lugar del cautivo cristiano. Pero si el cautivo cristiano no quiere salir libre a cambio de él, su dueño lo recupere, si quiere, restituyendo lo que recibió".

${ }^{46}$ Fuero de Cuenca, capítulo XXX,30; Fuero de las Cabalgadas, título LXXXI.

${ }^{47}$ Partida II,26,26: “[...] Otrosi fue puesto antiguamente por derecho, que los que siguiessen el apellido, e tirassen a los enemigos los omes, que leuassen presos de otra Ley, que non fuessen antes captiuos, que non ganassen ningun derecho en ellos; mas que los tornassen a aquel lugar, onde los auian leuado, o los dexassen yr quitamente, por do quisiessen. E si después que desta quisa los ouiessen dexado, se quisieren yr a los enemigos, ante que fincar con ellos, dende adelante quien quier que los prendiesse, deuen ser sus captiuos, también como si los ouiessen de guerra: e esso mismo 
Los textos medievales establecían un pequeño estatuto jurídico con respecto a los musulmanes capturados. Así en el caso de maltratos o muertes contra los prisioneros, los Usatges establecían que se abonase al señor el valor que tuviese el cautivo lesionado ${ }^{48}$; el Fuero de Cuenca ordenaba el que hiriese al moro de otro debía pagar 5 sueldos y, si lo matase, 15; pero si era un moro de redención, tal como debía demostrar su dueño mediante fianzas, debía abonarse la cantidad que se había prometido por otro moro cualquiera, siempre y cuando no superase 15 maravedís $^{49}$. En cambio, el de Teruel establecía que se pagasen al dueño del moro 15 maravedís alfonsís y, si fuera de redención, el precio de la misma ${ }^{50}$. El Fuero de Sepúlveda, por su parte, aplicaba la pena de 10 maravedís al cristiano que fuese descubierto in fraganti golpeando a un moro o a una mora y le causase moratones; si no fuera de ese modo, el cristiano se libraba de la sanción jurando que no lo hizo. En el caso de que matase al musulmán cautivo, debía pagar una caloña de hasta 100 maravedís al dueño del moro, siempre que fuera pillado in fraganti o que fuera denunciado aportando el testimonio de dos vecinos. Si el homicida presentaba el testimonio de cinco parientes y de cinco vecinos de Sepúlveda asegurando que no había tenido nada que ver en el homicidio del musulmán, era libre ${ }^{51}$. En Salamanca, por su parte, el que hiriese a un moro o mora con puñetazos, tirones de pelo o patadas, pagaría un maravedí; si lo hiriese utilizando armas, pagaría 2, y si lo matase, pagaría el valor del cautivo ${ }^{52}$. La misma regulación encontramos en Ledesma, estableciendo, en cambio que si lo hiriese con armas serían 3 maravedís ${ }^{53}$. En Viguera y Val de Funes, el que matase o hiriese con hierro a un moro debía pagar una caloña de 500 sueldos, mientras que el resto de heridas sería de 60 sueldos $^{54}$

El Fuero de Alba de Tormes distingue las agresiones contra moros según fuese o no de mierce. En el primer caso se ordena lo siguiente: "Todo omne o muler de

sería, quando los enemigos touiessen a tales omes, como estos, presos en su saluo, e los soltassen, auiendo piedad dellos, porque sopiessen que eran de su Ley; e aquellos después que fuessen sueltos, non quisiessen tornar al lugar do aduxeran, podiéndolo fazer".

${ }^{48}$ Usatge 21: "Malefacta in saracenis captivis emendentur ut servorum dominis suis; eorum vero mors secundum illorum valorem. Ideo dixit quia quidam sunt ex magna redempcione, quidam vero artifices experti ex diverso genere magistrorum".

${ }^{49}$ Fuero de Cuenca, capítulo XI,19.

${ }^{50}$ Fuero de Teruel, capítulo 36.

${ }^{51}$ Fuero romanceado de Sepúlveda, título 44: "Todo omne que firiere ferida de livores a moro o a mora cativo, si ge lo connoçieren, peche diez mrs.; si non, salves por su jura, que lo non fizo, e partas d'el. Et sil matare, e lo connocieren quel mató, peche la calonna al sennor de quien fuere el moro, de quantol fiziere, con dos vezinos, por sus juras, fasta cient mrs. o dent ayuso; e si dixiere quel non mató, salves con çinco parientes e cinco vezinos quel non mató, e partas d'el. E si este salvo non cumpliere, peche las calonnas, assí commo sobredicho es".

${ }^{52}$ Fuero de Salamanca, capítulo 60: "Qvien ferier moro o mora conpuno o acabellos, a coçes, peche.I. morauedi; e si lo ferier con qual arma quiere, peche. II. morauedis; e si lo matar, peche a su dono el moro qual lo feçier".

${ }^{53}$ Fuero de Ledesma, capítulo 29 (Ibíd.): “Quien firir moro o mora con punno o por cabellos o coçes le dier, peche. I. morauedi; e silo firir con qual fur, peche. III. morauis; et si lo matar, peche lo asu dueno qual llo fizier".

${ }^{54}$ Fuero de Viguera y Val de Funes, capítulo 460. 
Alba o de su termino que moro o mora ouiere, e de mierce fuere, qui gelo furtare, $e$ uencido fuere, e destaido ouiere, peche doblado quanto ouiere el moro destaiado, e las nouenas a palacio; e qui gelo matare, e uencido fuere, peche tanto por quanto ouierte destayado. E si dixiere el amparador: "non tayara tu moro nin tu mora por tantos morauedis", firme el demandador con.III. uezinos posteros, e el otro pecho el coto. E si dixiere el demandador: "non he la firma por quanto destaio", si el amparador uenzido fuere, peche. XXX. morauedis. E quilo firiere al moro oa la mora con armas uedadas, si uencido fuere, pecho .X. morauedis; si lo firiere con punno o lo messare, si uencido fuere, peche. $V$. morauedis. E si moro o mora firiere a cristiano oa cristiana con armas uedadas, e lo pudieren uencer, corten le la mano; e si matare, fagan le del corpo iusticia. E si niego fuere donno de moro o de mora que non mato, firmelo el demandador con .III. uezinos posteros que gelo uioron matar; e si firmar, fagan le del corpo iusticia; e si non firmar, partan se del. E si dixiere el demandador: "non he la firma", iure dueno de moro con .XII. uezinos posteros, e partan se del; e si non iurare, de el cuerpo del moro a iusticiar. E si firiere con armas uedadas o messare $o$ diere punno, silo pudieren uenzer, corten le el punno; e si dixiere donno de moro o de mora: "non firio nin messo nin dio punno", firme el demandador con.III. uezinos posteros; e si firmare corten le la mano; e si non ouiere la firma, iure el donno de moro $o$ de mora con .II. uezinos, e partan se del. E por esta demandanza de cristiano a moro o de moro a cristiano, de.VI. morauedis arriba, el amparador o el demandador se quisiere alçar ala real potestat, los alcaldes non lo uieden ende, e en plazen las por ala; e sinon cayales enperiuro, e el amparador non responda" 55 . Mientras que en los casos en que no fueran de mierce se dispone que: "Todo omne o muler de Alba o de su termino que moro o mora ouiere, qui gelo furtare o gelo matare, si fuere labrador e non fuere de mierza, peche.XXX. morauedis si lo pudieran uenzer. E si dixiere el amparador, "non furte tuo moro nin tua mora", firme el demandador con.III. uezinos posteros; e si firmare, por la morte peche.XXX. morauedis; e si fuere por furto, peche .XXX. morauedis doblados, e las nouenas a palacio. E si el demandador non ouiere la firma, iure el amparador con.III. uezinos posteros; e si non iurare, pecho el coto. E si el amparador o el demandador se quisieren alzar ala real potestat, los alcalles en plazen los pora ala; e si non cayales en periuro, e el amparador non responda" 56 .

Finalmente, en Plasencia se castiga con las heridas producidas al moro, siempre que no se hagan moratones, con un maravedí, y con dos si apareciesen. Si quebrase algún miembro, se pagarían cinco y si fuere delante del señor, se abonarían quince, pudiéndose librar en infractor en este caso si presentase fianza de salvo con tres vecinos o hijos de vecinos. Si se matase a un moro que fuere caballero, la multa a pagar sería de treinta maravedís, si de remisión, el valor de ésta que fuere concertado. Por último, si el moro era o no era menestral, se debía abonar quince maravedís ${ }^{57}$.

\footnotetext{
${ }^{55}$ Fuero de Alba de Tormes, capítulo 90.

${ }^{56}$ Ibíd., capítulo 89.

${ }^{57}$ Fuero de Plasencia, capítulo 62: "Todo omne que moro o mora firiere e liurores non feziere, peche .I. morauedi. Si liuores fiziere, peche.II. morauedis e por miembro quebrantado peche.V. morauedis. Si lo firiese ante su sennor, peche. XV. morauedis si pudiere firmar; si non, saluesse con tres uezinos o fijos de uezinos. Si fuere el moro cauallero, qui lo matare, peche. XXX. morauedis.
} 
Si era el musulmán cautivo el que mataba a un cristiano, el Fuero de Teruel retomaba la antigua institución romana de la noxae deditio, pues el dueño del cautivo podía optar entre pagar la caloña relativa al homicidio o entregar el musulmán en manos de los que hubieran denunciado el crimen para que dispongan de él ${ }^{58}$.

En el caso de heridas sufridas por cristianos efectuadas por musulmanes cautivos, en Salamanca y en Ledesma, si el dueño jura que no lo hizo, no tendría que pagar caloña ${ }^{59}$. Los Fueros de Aragón, por su parte, establecen que el moro que negase haber herido a un hombre o a una bestia, será probada su confesión si aportase el testimonio de dos cristianos "leales"; pero si no pudiere hacerlo, entonces el señor debería jurar que el moro no hizo tal daño ${ }^{60}$

Si se violase a una mora ajena, el Fuero de Cuenca ordena que el violador entregue arras como si se tratase de una muchacha desposada de la ciudad ${ }^{61}$. Si tuviese un hijo, éste sería esclavo del señor de la mora, hasta que su padre lo redima. En caso de sucesiones, el hijo no podrá heredar a su padre hasta que alcanzase la libertad ${ }^{62}$.

A los musulmanes que se les encontrase robando in fraganti, el fuero de Salamanca ordenaba que fueran entregados por sus dueños inmediatamente a la justicia municipal para ser ajusticiados, pues en caso de negarse serían multados con diez maravedís. Si la suma robada fuera superior a 1 maravedí, el dueño del musulmán se libraba de entregarlo si juraba con dos vecinos, pero sí no podía hacerlo, entonces debía pagar el robo conforme al Fuero ${ }^{63}$. El de Ledesma, por su parte, ordenaba al dueño entregar al moro a las justicias y, si no lo diese, una multa de cien maravedís ${ }^{64}$.

Las fugas de los musulmanes prisioneros de territorio cristiano también estaban previstas en los textos cristianos, pues se reconocía que alcanzaba la libertad cuando llegaba el fugitivo al territorio musulmán, tal como establecían las Partidas ${ }^{65}$. El

Si fuere de remission, peche por aquella remission que fuere aplazada por él si el sennor de la remission pudiere firmar que ya era fecha. Por otro moro si quier sea ministral o non, non peche si(non) .XV. morauedis, commo dicho es".

${ }^{58}$ Fuero de Teruel, capítulo 35: "Si moro catiuo ad algún cristiano matare, el sennor de aquel moro peche las calonias del homizilio, assin como es fuero, o metta el moro dannador en manos del querelloso, que el querelloso de aquel moro faga a su propria uoluntat, et aquesto sea en electión del sennor del moro".

${ }^{59}$ Fuero de Salamanca, capítulo 61: "Moro que ferier achristiano e lo negar, iure el dueno del moro que no ferio nin messo, e salga de calonnia"; Fuero de Ledesma, capítulo 30: "Moro que firir a christiano, si negar, iure el duenno del moro si quinto que non firio njn messo, e ixca de calonnia".

${ }^{60}$ Fueros de Aragón, libro III,161 (ed. de G. Tilander, 1937).

${ }^{61}$ Fuero de Cuenca, capítulo XI,22

${ }^{62}$ Ibíd., capítulo XI, 3.

${ }^{63}$ Fuero de Salamanca, capítulo 109.

${ }^{64}$ Fuero de Ledesma, capítulo 57.

${ }^{65}$ Partida III,28,20 y Partida VII,14,23: "Furtan a si mismos los sieruos, quando fuyen de sus señores con intencion de non tornar a ellos; pero el sieruo que se fuyesse assí, non se puede perder por tiempo a su señor; ca quando quier que lo falle, puedelo demandar en juyzio, e tornarlo a su seruidumbre. Fueras ende, si el sieruo fuesse a tierra de Moros, e desque fuesse ya en saluo e en su libre poder, se tornasse despues por su libre voluntad en la tierra de los Christianos, para andar y 
Fuero de Salamanca recompensaba al que capturase al cautivo fugitivo con medio maravedí si lo localizaba entre Peña del Rey hasta la Sierra; con 1 maravedí si era más allá de la Sierra y con un cuarto de maravedí si era aprisionado entre la ciudad y la Peña del Rey ${ }^{66}$. El de Ledesma, por su parte, recompensaba con medio maravedí sí el cautivo era preso en algún lugar comprendido entre la localidad y la Sierra, y con un maravedí si era más allá de la Sierra ${ }^{67}$. Los Usatges, por su parte, establecen la recompensa de un mancuso si se captura antes de llegar al Llobregat; de tres mancusos y medio, si se produce el suceso entre el Llobregat y el Francolí; y de una onza de oro, junto con los hierros y vestiduras del cautivo, si la captura se produce más allá del río Francolí ${ }^{68}$.

El que ayudase a los moros fugitivos, conforme a los Fueros de Aragón, debía abonar íntegramente el valor del daño causado al señor del cautivo ${ }^{69}$, siempre y cuando sea probado por testigos o por otro medio de prueba ${ }^{70}$; pero si llevase a los moros a su tierra, sin la voluntad de su señor, será despojado de todos sus bienes, debiéndose entregar al rey o a sus agentes, las personas de liberador como las de los moros ${ }^{71}$. Las Partidas, por su parte, castigan a los ladrones de siervos ajenos, si se trata de hidalgos, con que se les pongan hierros y trabajen en las tierras del rey, mientras que si son de otra condición, se les aplica la pena de muerte, agravándose en el caso de los esclavos con la muerte por bestias bravas ${ }^{72}$

como Moro de paz, e forro. Ca estonce, maguer lo fallasse ay su señor, non lo podria tornar en su seruidumbre; porque el señorio que el auia sobre el, se perdio luego que el fue llegado a tierra de Moros, e torno en la libertad en que era ante que fuesse captiuo. Esso mismo dezimos que seria, si el sieruo anduniesse fuydo a su señor treynta años en tierra de Christianos, seyendo todaúia desapoderado el señor de la possession del; ca de alli adelante, maguer lo fallasse, non lo podria demandar en juyzio, para tornarlo en seruidumbre [...]".

${ }^{66}$ Fuero de Salamanca, capítulo 265.

${ }^{67}$ Fuero de Ledesma, capítulo 179.

${ }^{68}$ Usatge 116: "Sarracenis in fuga positis, quincunque eos invenerit et retinuerit antequam transeant Lupricatum, reddat eos dominis suis, et pro mercede sua habeat de unoquoque singulos mancucios; a Lupricato usque ad Francolinum, man [cu]cios tres; deinde unciam [unam auri] et ferros et vestimenta".

${ }^{69}$ Fueros de Aragón, libro III,152: "Tot omne que trobará moros catiuos e los gyará e les toldrá los fierros o los çepos por que el sennor los pierda, pues que le fore prouado leal mientre, assi como deue, es tenudo de refer todo el danno entegra ment al sennor de los catiuos".

${ }^{70}$ Vidal Mayor, libro VIII,17 (ed. de G. Tilander, Lund, 1956): "Qui quiere que soltare al moro captiuo o lo acare de la cárcer, todo el daynno que el seynnor d'aqueill moro recebió por tal soltamiento deue li emendar, si esto li fuere prouado por testigos o por otra manera que sea abastant".

${ }^{71}$ Fueros de Aragón, libro VII,276: "To omne qui fore trobado leuando moros a tierra de moros sin uoluntat de lures sennores, deue seer espullado de todos sos bienes, tan bien el qui los lieua como el moro a qui lieua, d'aquel qui los trueba qui quier sea, e deue seer suyo. Enpero los cuerpos d'ellos, ço es del qui los lieua e de los moros, deuen seer rendidos al rey o al merino del logar o aquesto achaeciere".

Vidal Mayor, libro VIII,16: "Quoando quiere et do quiere que iudio o cristiano leuare al moro, sin uoluntad d'aqueill de qui es, a la tierra de los moros o los alogaren, el qui assi lieua et el moro que assí es leuado espuillados de todos los sus bienes pora aqueill que assí faillare a eillos. Istud non dictauimus, esto non ditámos como deuen ser puynnidos: Et los sus cuerpos sean presos pora el rey o por su baille".

${ }^{72}$ Partida VII,14,22: "Sosacan, o furtan algunos ladrones los fijos de los omes, o los sieruos 
El dueño del fugitivo puede enviar agentes con la misión de investigar los lugares donde puede haberse ocultado, pudiendo investigar en las casas donde sospechase que se había refugiado y sin que los dueños de las mismas puedan oponerse a ello, como se declara en los Fueros de Aragón ${ }^{73}$. En Castilla, el dueño debe acudir al juez del lugar donde cree que el cautivo fugitivo se ha ocultado y comunicárselo, para que se le faciliten permisos y hombres para realizar la búsqueda. Sí el juez no se lo permitiese o el propietario de la casa donde se sospechase que se oculta el fugitivo no le dejase entrar a inspeccionar, "deue pechar a la Cámara del Rey cien marauedis de oro por tal rebeldía como ésta. E demás desto, deuen escodriñar la casa, por saber si es ay el sieruo, o non. Otrosi dezimos, que todo ome que rescibiera a sabiendas sieruo que se fuyere a su señor, o lo escondiere, que deue pechar porende cien marauedís de la moneda sobredicha a la Cámara del Rey, e a su señor el sieruo doblado. Pero si fasta veynte días, desde el día que lo rescibió a sabiendas, lo manifestare al señor del sieruo, o al Judgador del lugar, como lo tiene en su casa; estonces, deuele perdonar la pena de los cien marauedís. Pero es tenudo de dar al señor el sieruo doblado, porque lo encubrió tanto tiempo. E si por auentura, non ouiesse otro sieruo que dé, con aquel que encubrió deue pechar por el veynte marauedis de buena moneda, en lugar del otro que auia de dar por pena"74.

El cautivo lograba la libertad siempre que se produjera el pago del rescate. La conversión al cristianismo del musulmán no llevaba consigo su liberación en Aragón, pues el Derecho territorial ordenaba que todavía permaneciese bajo el poder del señor hasta que hubiese abonado el precio de la compra, pero "deve firmar aquel sennor en poder de la egelsia e de nuestra iusticia con buena carta que él que nol faga peyor presón que dantes, e que nol dé mal solaz, mas quel cate bien e quel faga lavrar como dantes fazía del menester que sabía. E sacada su vianda e so vestir, todo lo que ganará aquel baptizado todo lo deve su sennor prender en paga del precio de li costa e que passe a si estro que sía pagado, si doncas otra conviença non fazen entre ellos. E pagado el precio, que sía suelto e franco en todo logar"75.

En la Corona de Castilla, en cambio, si se reconoce la libertad al musulmán que se convierte al cristianismo, como en los Fueros de Salamanca y de Ledesma,

agenos, con intención de los lleuar a vender a tierra de los enemigos, o por seruirse dellos como de sieruos. Es porque estos atales fazen muy gran maldat, merecen pena. E porende dezimos, que qualquier que tal furto como este fiziesse, que si el ladrón fuere fijodalgo, deue ser echado en fierros, e condenado para siempre que labre en las lauores del Rey. E si fuere otro ome que non sea fijdalgo, deue morir porende. Esi fuere sieruo, deue ser echado a las bestias brauas, que lo maten. Essa mesma pena ha lugar en todos aquellos, que dan, o venden ome libre, e los que lo compran, o resciben de otra manera en don a sabiendas, con intención de se seruir del como de sieruo, o venderlo".

${ }^{73}$ Fueros de Aragón, libro VIII,320: "Aquest qui perdiere catiuo o catiua, los messageros d'el puedan cercar e demandar amorosa mientre quales quier e quantas quier casas sospeytosas de cristianos o de iudios o de moros, demandando so catiuo o so catiua que perdió, et aquest escodrinamiento no lo deue uedar negún omne qui quier se sea, qual, si lo fiziere, sea costrenido de soffrir aquest escodrinamiento por el iuge o la cort del logar".

${ }^{74}$ Partida VII,22,24.

${ }^{75}$ Fueros de Aragón, libro VII,296 (ed. de A. Gargallo Moya, Zaragoza, 1992). 
si su señor le otorga carta en la que lo declare por tal, haciendo prueba frente a terceros ${ }^{76}$.

Las Partidas, por su parte, no dicen nada en los casos de conversión del musulmán cautivo, pero establecen determinados supuestos en los que se puede conseguir la libertad sin necesidad de pago del rescate: $i$ ) por aquellos actos en los que la ley o el monarca juzgaban que era digno de conseguir tal recompensa ${ }^{77}$;

${ }^{76}$ Fuero de Salamanca, capítulo 241: "Todo moro o mora que se tornar christiano, e su senor el fezier carta de libertade, e a alguno algo dier acondesar, e le la negare, se ouier casa en uilla, lidie; e se non, tome el fierro; qual quesier duenno de la carta".

Fuero de Ledesma, capítulo 164: "Moro o mora que se tornar christiano, e su senor lle fizier karta de enegenuydade, e algun omne la dier acondesar, e lle la negar, se ouier casa enuilla, llidi; e se non, entre al fierro; qual quesier duenno dela karta".

${ }^{77}$ Partida II,27,6: “Noble razón han los gualardones, que pueden ser fechos en los omes quando fazen seruicios señalados a sus Señores en guerra. assí como diximos. Más non lo puede fazer otro, si non Emperador, o Rey, o otro Señor, a quien conuenga, e aya poder de fazer todas estas cosas en su Señorio; assí como dar heredamiento cumplidamente, o cambiar los omes de vn estado en otro, segund tuuiere por bien. E porende quando alguno fiziesse al Rey los seruicios, que de suso diximos que fazen los vassallosa los otros Señores, puede el gualardonargelo como los otros. E demás, a los que le ayudaren a ser heredado de lo de sus enemigos, puedelos heredar de mayores heredamientos, e de mejores, e franquearlos, también en las heredades que son de los otros en su Señorio, como en las de su realengo. Otrsí, a los que lo honrrassen de sus enemigos, matando el Cabdillo de la otra parte, o prendiéndolo, puedeles dar honrra de fijosdalgo, a los que lo non fueren por linaje. E al que fuesse sieruo de otro, puedelo el fazer libre. E si fuere pechero, quitarlo de pecho, non tan solamente en lo suyo, más aun en lo de los otros, segund de suso diximos. Otrosí ha poder de los guardar de mal estado, e ponerlos en bueno, a aquellos que su cuerpo del Rey guardassen de daño de sus enemigos, sacándolo de su poder, si lo tuuiessen presso, o lo quisiessen prender; e le desuiassen el golpe, o se parassen ante él, quando lo quisiessen ferir; o le diessen el cauallo, si le matassen el suyo. Ca tales omes como estos, porque sacaron a él del mal estado, puédelos el poner en el estado de los mayores, mostrándoles honrra, e faziéndoles bien en cauallería, o en casamiento, o en otra cosa, que entiendan los omes, que han cumplidamente su amor. E segund esto dezimos, del que alçasse su seña, si los enemigos la ouiessen derribado, o la tomassen por fuerça, al que la ouiesse tirado al Alferez de su Señor el Rey. Ca a tal como este puédelo él por derecho alçar entre los otros de su linaje, en bien $e$ en honrra, por éste fecho señaladamente. Ca los Sabios antiguos, que todas las cosas cataron, tuuieron por bien, e por derecha razón, que atales fechos como estos fuessen gualardonados a los omes que los fiziessen; maguer ouiesse algunos dellos, que non lo meresciessen por linaje, nin por otra bondad, que en ellos ouiesse. E estos fizieron por tres razones. La primera, porquel conosciessen los omes Señorio natural, que es sobre todas las otras cosas, e lo sopiessen honrrar, auenturándose a darle honrra de sus enemigos, e guardarle otrosi también de daño de los enemigos. La segunda razón fue fallada, porque se esforçassen a fazer lo mejor, metiéndose a grandes peligros, por ganar bondad, e honrra. La tercera, porque pudiessen acabdillar a si mismos, guardándose de fazer cosas que les estuuiessen mal, sufriendo afán, e miedo, para fazer lo mejor. Más si otros omes honrrados $e$ de buen lugar, fiziessen alguna cosa destas sobredichas, deuéles el Rey fazer gualardon porende en tres maneras. La primera, loándoles el bien fecho que fizieren. La segunda, gradesciéndoles de palabra el seruicio que por ellos rescibió. e estas son cosas, que esfuerçan, e alegran los coraçones nobles, para fazerlo todavía mejor. La tercera, guarlardonángelo de fecho, e acrescentándoles en su bien, e en su honrra. E por ende tuuieron por deercho otrosí, que qualesquier que en estas maneras sobredichas errassen contra sus Señores, que sin el mal que le farian mostrándose por malos e por viles de coraçones; solamente por la trayción que les y cabría, en non querer guardar, ni honrrar el Señor natural; ni a su Rey, que perdiessen ellos los cuerpos, e lo que ouiessen, como traydores. E si acaesciesse que el Rey fuesse muerto o presso, que fincassen sus casas derribadas, e yermas para en siempre. E los que dellos descendiessen derechamente, que fuessen echados de la tierra por 
ii) por manumisión realizada por el dueño al cautivo ${ }^{78}$; iii) cuando la sierva es destinada a la prostitución ${ }^{79}$; y iv) por razón de matrimonio ${ }^{80}$.

toda vía. Lo vno, por vergüença del mal que fizieran aquellos de quien ellos vienen; lo al, por el escarmiento, que los que lo oyessen, se guardassen de fazer otro tal. Pero esto non se entiende de los hijos, que ouiessen fecho ante que errassen; más de los que después fiziessen, siguiendo ellos de tan mala ventura, que biuos fincassen. Ca los derechos, que fallaron los Antiguos de España en todas las cosas, alli do pusieron pena a los fijos por razón de sus Padres, siempre guardaron esto, que non ouiessen pena los que ante auian, que el fecho malo fiziessen fueras ende si fuessen con ellos aparceros en los yerros. E a los otros que metieron en la pena, fue porque lo fizieran después que estauan ponçoñados en el mal, que ouiessen fecho; teméndose, que en alguna razón recudiessen a aquellos mesmos. Porende mandaron, puque fuessen destruydos de guisa, que nunca diessen fazer mal, ni la tierra fincasse porende denostada, e los otros que lo oyessen, tomassen ende escarmiento. Como quier que segund las leyes de los Emperadores, los fijos destos omes atales non deuen auer esta pena, segund adelante se muestra en la setena Partida, en las leyes que fablan en esta razón"; Partida IV,22,3: "Merescen las vegadas los sieruos por si mismos ser aforrados, por bondades que fazen, maguer non los aforren sus señores. E esto puede ser por quatro razones. La primera es, quando algún sieruo faze saber al Rey, o alguno de los que judgan por él, como algún ome forço, o lleuo robada alguna muger virgen. La segunda, quando descubre a ome que faze moneda falsa. La tercera es, quando descubre alguno, que es puesto por Cabdillo de Caualleros, o de otros omes en frontera, o en otro lugar, por mandado del Rey, si los desamparo sin otorgamiento del Rey. Esso mismo sería, si descubriesse a Cauallero que desamparasse en tal lugar al Rey, o a otro Cabdillo. La quarta es, quando acusasse al que ouiesse muerto su señor, o lo vengasse, o descubriesse trayción que quisiessen fazer al Rey, o al Reyno. Pero en las tres razones primeras, el Rey, o el otro Señor ante quien las descubriesse, deue dar al Señor tando precio, quanto vale el sieruo".

${ }^{78}$ Partida IV,22,1: "Libertad es, poderio que ha todo ome naturalmente; de fazer lo que quisiere; solo, que fuerça, o derecho de ley, o de fuero non gelo embargue. E puede dar esta libertad el señor a su sieruo, en Eglesia, o fuera della; o delante del Juez, o en otra parte; o en testamento, o sin testamento, o por carta. Pero esto deuc fazer por si mismo, e non por personero; fueras ende, si lo manda fazer a algunos de los que descienden, o suben por la laña derecha del mismo. Mas ha menester, que quando lo aforrare por carta, o delante sus amigos, que lo laga ante cinco testigo. E si lo quisiere aforrar en testamento, non lo puede fazer, a menos de auer catorze años el señor quel aforra. E si lo quisiere aforrar de otra manera por carta, o delante testigos, o amigos, non lo puede fazer, a menos de auer el señor veynte años; fueras ende, si aquel a quien quisiesse aforrar, fuesse su fijo, o su fija, que ouiesse de alguna su sierua; o si fuesse su padre, o su madre, o su hermano, o su hermana; o su maestro que le enseñasse; o su amo, o su ama, quel criasse; o si fuesse su criado, o su criada; o si fuesse con el criado a leche de vna mager; o si fuesse tal sieruo, que ouiesse librado a su señor de muerte, o de mala fama; o si quisiesse aforrar a alguno de sus sieruos, para fazerlo procurador, para recabdar sus cosas fuera de juyzio, auiendo el sieruo a lo menos diez y siete años complidos; o si aforrasse su sierua, para casar con ella. Pero en este caso deue jurar, que por tal razon la aforra, e que casara con ella, fasta seys meses. Ca prouando el señor qualquier destas cosas sobredichas, delante del Juez, el que fuesse menor de veynte años, e mayor de diez e siete, bien puede aforrar su sieruo; faziendolo todavia con otorgamiento de su guardador".

${ }^{79}$ Partida IV,22,4: "Poniendo alguno sus sieruas en la puteria publicamente, o en casa alguna, o en otro lugar qualquier, que se diessen a los omes pordineros; establescemos, que por tal enemiga, como esta, que les manda fazer, que pierda el señor las sieruas, e sean ellas porende libres. E mandamos, que los que lo judgaren por Nos en el lugar do esto acaesciere, que lasparen, que las non pueda tornar en seruidumbre jamas, aquel que era su senor, nin aya ningund derecho en ellas".

${ }^{80}$ Partida IV, 22,5: "Casando sieruo alguno con muger libre, sabieudolo su senor, e non lo contradiziendo, fazesse el sieruo libre porende. Essomismo dezimos que seria, si casasse la sierua con ome libre. E aun dezirnos, que si el senor se casasse con su sierua, que sería la sierua libre porende". 


\section{El CAUTIVO CRISTIANO EN LOS TEXTOS MEDIEVALES CRISTIANOS}

El cautivo cristiano es configurado como prisionero de los moros en los textos medievales cristianos. Son raras las alusiones a los casos en que los cristianos cautivan a gente de su fe, a las que ya nos referimos al comienzo de este trabajo.

Es necesario que cuanto antes el cautivo cristiano alcance pronto la libertad, dando las Partidas para cuatro razones morales y religiosas ${ }^{81}$, que son un desarrollo de la misión de Cristo en la tierra ${ }^{82}$ :

i) "Porque plaze a Dios, de auer ome dolor, de su Christiano, ca segun el dixo, assi le deue amar como a si mesmo, quanto en la Fe";

ii) "Por mostrar y piedad, que deuen los omes de aquellos que mal resciben, porque son de vna natura, e de vna forma";

iii) "Por razon de auer gualardon de Dios, e de los omes, quando le fuere menester: ca bien assi como el querria ser acorrido, si yoguiesse en captiuo, bien assi deue el acorrer al que en el yoguiere"; $\mathrm{y}$

iv) "Por fazer daño a los enemigos, cobrando de ellos los que tienen presos de su parte, sacandolos de su poder. Ca esta es cosa en que yaze pro, e honrra a los que lo fazen, e los otros resciben por ello perdida, e mengua".

Estas razones son suficientes para justificar la liberación del cautivo, incluso pagando un rescate, pues non se deuen agrauiar de lo que y dieren. Ca el auer passa segun el mundo, e pierdese, e non finca dello otra remembrança, si non lo que es bien empleado. Además, hay que tener en cuenta la promesa de salvación que hizo Cristo para el día de Juicio Final cuando dice "estaba... en la cárcel y vinisteis a verme" $"$.

¿Quién está obligado a procurar la libertad de los cautivos? Según las Partidas, existen cinco relaciones que vinculan a una persona a liberar al cautivo ${ }^{84}$ :

i) Por profesar la misma fe, por las razones dichas más arriba;

ii) Por pertenecer al mismo linaje. Los hijos tienen la obligación de no alargar el cautiverio al padre o a otros parientes, pues si no lo hace así, puede ser desheredado, "porque se muestran por cobdiciosos, e dan a entender, que por qualquiera manera, auian sabor de heredar lo suyo, e de los que yazen captiuos; y también, porque fazen muy grande crueldad, non se doliendo ome de su linaje, que esta en seruidumbre, e en peligro de muerte" ${ }^{85}$. Sin embargo, si el hijo o el pariente son menores de dieciocho

${ }^{81}$ Partida II, 29,2.

${ }^{82}$ Lucas, 4,18: "El Espiritu del Señor está sobre mí, porque me ha ungido para anunciar a los pobres la Buena Nueva, me ha enviado a proclamar la liberación a los cautivos y la vista a los ciegos, para dar la libertad a los oprimidos".

${ }^{83}$ Mateo, 25,36.

${ }^{84}$ Partida II,29,3.

${ }^{85}$ Téngase en cuenta también lo contenido en la Partida VI,7,6, que establece como causa de desheredación esa falta de respeto cometida por los hijos al padre, aplicando también esa pena general establecida al final del precepto que ahora se comenta, tomado del Derecho justinianeo, como se indicara a continuación: "Captiuando algun ome, o muger, que ouiesse fijo, si los fijos fuessen negligentes, non auiendo cuydado de redemir su padre, o su madre, o lo dexassen captiuo, podiendolo redemir, si despues desto saliere este atal de poder de los enemigos, puede por esta razon desheredar sus fijos. Mas si por auentura muriesse en poder de los enemigos, 
años, no se les aplica esta causa de desheredación ${ }^{86}$.

La misma sanción de desheredación a los hijos que no liberan a sus padres la encontramos también en los Fueros de Aragón ${ }^{87}$.

Junto a los hijos o parientes, las Partidas incluyen en este apartado a aquellas personas que no perteneciendo al linaje del cautivo éste en su testamento las había nombrado herederos; tienen la obligación de intentar liberarle, siendo desheredados si no hacen nada ${ }^{88}$.

aquellos que le deuian heredar, que fueron negligentes en sacarle de captiuo, non deuen heredar ninguna cosa de los sus bienes. Mas el Obispo de aquel logar, onde era natural este que murio en la captiuidad deue entrar todos sus bienes, e fazer ende escrito cierto de quantos son; e despues desso, deuelos vender todos, e dar el precio en redencion de captiuos. Ca, pues que este era señor, no se aprouecho de sus bienes, nin fue redemido dellos, bien es que sean otros redemidos en su logar. $E$ lo que diximos en esta ley de los fijos, entiendase tambien de los otros parientes, que auian debdo de parentesco con el captiuo [...]". También el Fuero Real, libro III, título IX, ley 2, establece en este supuesto la desheredación de los descendientes directos.

${ }^{86}$ Partida VI,7,6: "[...] E la pena, que diximos en esta ley, e en la que fabla del furioso, deuen auer tan solamente los parientes, e los herederos, que son mayores de diez e ocho años, e non los otros que fuessen menores desta edad, maguer errasen assi como sobre dicho es [...]".

${ }^{87}$ Fueros de Aragón, V,236: "Fillo qui fiere sabuda ment a so padre o a so madre e mayor mientre si lo tirare por los cabellos o si lo desmentiere delant buenos omnes o lo fará iurar en iudicio o en cort, deue seer deseredado de los bienes del padre o de la madre. Aquel inidicio es del fillo o de la filla qui non traye al padre o a la madre de captiuidat, si lo podiere fer, o si el fillo quisiere iazer con la muller de so padre. Enpero en qual quier d'estas maneras yerre el fillo contra el padre o la madre, bien pueden perdonar al fillo, si quisieren, el heredar lo. Encara el fillo o la filla qui faze tal cosa por qu'el padre o la madre pierden todo lo lur o alguna partida, pueden ellos desafillar delant la iusticia et en cort delant buenos omnes, et aquest fillo non deue heredar en los bienes del padre ni de la madre. Enpero, si el padre e la madre quisieren perdonar ad aquest fillo, bien lo pueden fer et heredar lo, assi como si non ouiesse fallido contra ellos. E si el padre o la madre no perdonassen ad aquest fillo deseredado en esta manera, si mueren sin destin, no le pueden toller so part de los bienes del padre e de la madre segunt fuero"; Vidal Mayor, VI,24: "Fjillo qui a sabiendas feriere al padre o a la madre, et mayorment si lo trayere por los cabeillos o lo esmentiere ante omnes bonos o lo fiziere iurar en iuditio o en otro loguar, por dreito deue ser desheredado tal fillo. Et eixo mismo es d'aqueill qui non quiso saquar al padre de captiuo et non lo quiso aiudar ni acorrer ni aconseillar, maguer podiés fazer aqueillo en bona guisa, e si iugo con la su muiller uelada de su padre. Empero en quoal se quiere d'estos ditos casos el padre o la madre puede perdonar ad atal fillo et poner lo en su gracia et poner lo en estado como a fillo. Et otrosí el fillo qui fizo tales cosas por las quoales cosas contesció que el padre perdió sus bienes o en partida, puede el padre desytar de la su conpaynnia et de su affillamiento ad aqueill fillo ante l'alcalde $o$ ante la cort o ante omnes bonos, la quoal cosa es clamada desaffillar en uulgo, es assaber del pueblo, el quoal fillo, si después non fuere recebido en la familia del padre et en estado que deue ser fillo de cabo d'aqueill padre qui lo desafilló en tal guisa, será desheredado ni aurá part en sus bienes del padre o de la madre. Quar, si empués tal desytamiento del padre fuere tornado al estado filial, deue ser clamado como fillo et deue heredar en los bienes d'aqueill padre, más si este fillo, de quoal fiziemos en mient a postremas, después que fuere desytado de la gracia del padre, nunqua fue después recebido d'aqueill padre qui assi lo itó de su gracia el del affillamiento et contesciere que muera sin destín, aqueill fillo segunt fuero deue heredar en los bienes d'aqueill padre, como si siempre ouiesse seido en su gracia".

${ }^{88}$ Ibíd.: "[...] Otrosi dezimos, que si alguno, ante que cayesse en captiuidad, ouiesse fecho testamento, en que si muriesse en poder de los enemigos, non lo queriendo ellos redemir, non valdria el testamento quanto en el establescimiento de los herederos, mas valdra en las otras cosas, segund diximos en la ley ante desta, que fabla del furioso". 
Los herederos del cautivo (hijos, parientes, extraños) no pueden alegar como causa de incumplimiento el no haber recibido mandato del causante para vender o empeñar sus bienes para lograr su libertad, "pues sin su mandado las podrian ellos vender, e obligar, tambien como las sus cosas proprias".

Si pagasen el rescate del cautivo, no podrán exigir a éste una vez liberado compensación económica alguna ${ }^{89}$.

iii) Por postura. El marido respecto a la mujer y viceversa, y el hijo adoptado. También incurren en causa de desheredación si no cumplen con su deber de liberar al cautivo. Si pagan el rescate, sucede como en el caso anterior, que no pueden exigir al cautivo el dinero pagado ${ }^{90}$.

iv) Por vasallaje. El vasallo tiene la obligación de sacar del cautiverio a su señor, no sólo utilizando sus bienes, sino también auenturar el cuerpo a muerte, $o$ a prision. En el caso que el vasallo no cumpliese con su deber, entonces el señor puede arrebatar todos los bienes que quisiese al vasallo. Pero el señor también está obligado a liberar al vasallo cautivo, pues si no lo hace, éste, una vez recuperada la libertad, puede desvincularse de su señor, "desnaturandosele por esta razon, e yrse a otro Señor, e fazerle guerra, e ser en su destruymiento, sin mala estança de sî".

v) Por amor de voluntad. Los amigos del cautivo también tienen la obligación de procurar su libertad. Pero si no lo hace, una vez que fuera liberado el cautivo "puedele dezir mal ante el Rey, mostrandole que vale por ello menos. E demas, si alguna cosa ouiesse de auer de lo suyo, deuelo perder".

Junto a cada sanción particular establecida en cada supuesto por no cumplir la obligación general de liberar al cautivo, la norma impone una pena general, en la que establece el destino de los bienes del cautivo muerto: "Pero si qualquier de la manera de los captiuos que diximos, por mengua de non auer quien lo sacasse, se muriesse en la prision, deue estonce el Rey, o el que estuuiesse en su lugar, tomar todo lo que ouiesse, o mandarlo meter en carta al Escriuano publico, e venderlo en almoneda, con consejo del Obispo, o del que touiesse sus vezes. E el precio, que por dello ouieren, darlo para sacar captiuos, porque lo sus bienes non sean heredados de aquellos que le dexaron morir en captiuo, podiendolo sacar, e non quisieron".

El propio cautivo (y como él también el prisionero), puede alcanzar la libertad si un tercero se la ofrece a cambio de alguna cosa o un precio. Una vez liberado, no puede el antiguo cautivo impedir el pago a su libertador o, si ya lo ha realizado, exigir la devolución de la cosa o el dinero entregado, a no ser que el libertador fuese un miembro del grupo que lo apresó o instigador del cautiverio ${ }^{91}$. En la

${ }^{89}$ Partida II,29,12: “Ciertas razones mostraron los Sabios antiguos, porque ome que sacare a otro de captiuo, pagando algun precio por el, non gelo podia despues demandar, nin seruirse del en ninguna manera. E estas son por cinco cosas [...]. La segunda es, por razon de piedad, e viene por debdo de naturaleza; assi como quando el padre saca al fijo de captiuo, o alguno de los otros que descienden del por la liña derecho, o el fijo al padre, o a la madre, o alguno de los otros que subiessen por ella [...]".

${ }^{90}$ Ibíd.: "[...] La tercera es, por razon de debdo de casamiento; assi conmo si vn ome, o muger sacasse vno a otro de captiuo, e se casassen despues en vno; o si quitasse el marido a la muger [...]".

${ }^{91}$ Partida V,14,48: "Catiuado, o preso seyendo algund ome en poder de enemigos, o de ladrones; si acaesciesse, que viniesse otro alguno a el que dixesse, que le diesse alguna cosa, e que le sacaria de aquella prision, el pleyto que assi fiziesse, tenudo seria de lo guardar, cumpliendo el otro lo que 
redacción de este precepto de las Partidas, el autor conjugó la teoría romana de los contratos innominados, y más concretamente, la figura jurídica del do ut facias ${ }^{92}$, con la de la condictio ob turpem vel iniustam causam ${ }^{93}$.

Si un tercero pagase el rescate del cautivo, las Partidas permiten que el libertador pueda retenerle en su poder hasta que recibiese lo que hubiese pagado o le sirviese durante cinco años. Si el antiguo cautivo, antes de pagar o de concluir el servicio debido, huyese y fuese atrapado, debe ser entregado al que pagó el rescate $^{94}$.

El cautivo puede alcanzar la absoluta libertad si empeñase a otro en su lugar ${ }^{95}$. Lo

prometiera. E si le pagasse aquello que le prometio, non gelo puede despues demandar. Fueras ende, si el que recibiesse el precio, fuesse compañero de los otros quel prisieron, e se acertasse en prenderle; o fuesse ayudador, o consejador, que lo prisiessen. Ca estonce bien podria demandar, e cobrar lo que ouiesse dado en tal razon como esta. E lo que diximos en esta ley de la prision, o del catiuamiento del ome, ha logar otrosi en todas las otras cosas, que ome diesse, o prometiesse, por cobrar lo que le fuesse robado, ofurtado".

${ }^{92}$ D. 19,5,5,2 (Paul., 5 quaest.): "At cum do ut facias, si tale sitfactum, quod locari solet, puta ut tabulam pingas, pecunia data locatio erit, sicut superiore casu emptio: si rem do, non erit locatio, sed nascetur vel civilis actio in hoc quod mea interest vel ad repetendum condictio. Quod si tale est factum, quod locari non possit, puta ut servum manumittas, sive certum tempus adiectum est, intra quod manumittatur idque, cum potuisset manumitti, vivo servo transierit, sive finitum non fuit et tantum temporis consumptum sit, ut potuerit debueritque manumitti, condici ei potest vel praescriptis verbis agi: quod his quae diximus convenit. Sed si dedi tibi servum, ut servum tuum manumitteres, et manumissisti et is quem dedi evictus est, si sciens dedi, de dolo in me dandam actionem iulianus scribit, si ignorans, in factum civilem".

${ }^{93}$ D.,12,5,4,4 (Ulp., 26 ed.): "Si tibi indicium dedero, ut fugitivum meum indices vel furem rerum mearum, non poterit repeti quod datum est: nec enim turpiter accepisti. Quod si a fugitivo meo acceperis ne eum indicares, condicere tibi hoc quasi furi possim: sed si ipse fur indicium a me accepit vel furis vel fugitivi socius, puto condictionem locum habere".

${ }^{94}$ Partida II,29,11: "Sacando vno ome a otro de captiuo, maguer por el diesse cierta quantia de marauedis, o otra cosa de lo suyo, non se ha por esso de seruir del, como de sieruo, mas puedelo tener guardado, como en manera de peños, en razon de aquello que por el pago; e el otro non deue salir de su poder, fasta que le faga pagamiento, o le sirua por ello cinco años a lo menos, en aquellas cosas que le mandare, que sean guisadas de fazer, segund qual ome fuere. E si por ventura, ante que se compliesse este seruicio, o le ouiesse fecho paga de aquello por que lo quitara, fuyesse de su poder; si despues lo fallassen, e le pudiessen aueriguar por carta, o por testigos, ante el Señor o Juez de aquel logar, como lo tenia sacado de captiuo, e que le non siruiera, nin le pagara lo que por el auia dado, estonce aquel ante quien lo mostrasse, deuelo prender, y meter en poder de aquel que lo vino a demandar; e puede lleuar las missiones, que ouiesse fechas en buscandolo, e seruirse del, o fazerle pagar, lo que ouiesse dado para quitarlo, assi como sobredicho es".

${ }^{95}$ Partida V,13,3: "Santas cosas, e sagradas, e religiosas, assi como las Eglesias, e los monumentos, e las otras cosas semejantes, non las pueden los omes rescebir a peños, nin se pueden obligar. Fueras ende por cosas señaladas, segun dice el Titulo que fabla de las cosas de Santa Eglesia, en la primera Partida deste nuestro libro. Otrosi dezimos, que vn ome libre non se puede empeñar, Ante dezimos, que qualquier que lo recibiesse en peños, que deue perder todo lo que diesse sobre el. E deue pechar mas otro tanto de lo suyo a el, e a sus parientes, si por auentura el non fuesse biuo. Pero dos casos son, en que podria ome libre ser rescebido en peños, e fincaria obligado. El primero es, si alguno yoguiese catiuo, e el mismo se empeñasse a otro, por quitarse de catiuo. E el segundo es, si alguno empeñasse su fijo por cuyta de fambre. Otrosi dezimos, que ome libre puede ser dado en rehenes, por razon de paz que firmassen algunos entre si, o por tregua, o por otra segurança, o por otra cosa semejante destas. E maguer el pleyto sobre que fuesse alguno empeñado en esta manera, 
normal es que fuesen los hijos varones los que fueran enviados como rehenes para asegurar el pago del rescate, siempre y cuando mediase autorización del Concejo. Si en el plazo de tres años el padre no libera al hijo, el Fuero de Cuenca ordena que fuese apresado con todos sus bienes y enviado en sustitución del hijo ${ }^{96}$. Se prohíbe taxativamente enviar como rehén a las hijas.

Junto a los casos de los parientes y del matrimonio, las Partidas establecen determinados supuestos por los cuales no se puede exigir el pago del rescate hecho por un tercero ${ }^{97}$ :

i) "Como si el que lo quitasse, lo fiziesse señaladamente por amor de Dios; ca este non deue auer otro gualardon, si non aquel".

ii) "Por razon de yerro, que nasce de maldad: e esto seria como si alguno sacasse muger de captiuo, e despues yoguiesse con ella, o consintiesse a otro de lo fazer".

iii) "Por razon que nasce de sospecha; e esto seria, como si lo quitasse alguno de captiuo, e non le demandasse en su vida, que le pagasse aquello que auia dado por el. E esto se entiende fasta vn año, despues que lo ouiesse pagado: ca si muriesse despues de aquel plazo, e el otro non gelo ouiesse demandado en juycio, nin fuera del, e despues lo quisiesse demandar a sus herederos, non lo podria fazer, nin serian ellos tenidos de le responder por ello. Ca pues que ouo tiempo para demandarle lo que auia pagado por el, e non quiso, bien se entiende, que fue su voluntad, de nunca gelo demandar".

Un caso especial supone la liberación por medio de alfaqueque. Si el alfaqueque saca de su prisión a un cautivo cristiano, "o por auer, o por otra cosa que de por el, non señalando plazo, a que pague, maguer el otro non lo pudiesse tan ayna pagar, que le non tornen por esso a poder de los enemigos, mas que lo atiendan, fasta que gelo pueda dar. Pero esto se entiende, non lo faziendo maliciosamente el que ouiesse sacado de catiuo, assi como teniendo de que lo pagar, e non lo quisiesse fazer. Ca si esto le pudiesse ser prouado, estonce bien lo podria tomar, e tornar al lugar donde lo auia sacado: e esto mismo dezimos del catiuo, que el Alfaqueque sacasse a dia cierto, podiendolo pagar, e non quisiesse" ${ }^{98}$.

Mientras dura el cautiverio, los bienes del cautivo deben ser guardados y custodiados para evitar que fuesen adquiridos por fuerza o por engaño por terce-

non fuesse guardado, con todo esso, non deuen a el matar, nin ferir, nin darle pena ninguna, nin fazerle mal ninguno. Mas puedenle guardar, quanto tiempo touieren por guisado, o fasta que el tiempo se cumpla, assi como fue puesto".

${ }^{96}$ Fuero de Cuenca, capítulo X,39: "Cualquiera que envíe en su lugar a su hijo como rehén, al que el vulgo llama "refreno", a tierra de sarracenos, y no lo redima en el plazo de tres años, el Juez y los alcaldes aprésenlo con todos sus bienes y envienlo en lugar de su hijo a tierra de moros y liberen al hijo del cautiverio. Por esto mandamos, que cualquiera que dé en prenda a su hijo sin mandato del Concejo, o lo envie como rehén, si no es bajo la condición antedicha, muera con muerte de traidor. En modo alguno es lícito dar en prenda una hija, ni como "refrena" ni como empeño; y si alguien lo hace, sea quemado vivo. Si el Juez y los alcaldes no hacen justicia así, el Concejo tómeles prendas por la redención de la rehén o de la que ha sido empeñada. Lo que decimos sobre una hija, valga para cualquier mujer que haya sido dada en prenda o enviada como rehén; este precepto está establecido para que los moros no apremien a los cristianos; pues, como aseguran los que lo saben, los sarracenos jamás apremian a los cristianos, sino por la osadia de los cristianos que están con ellos y de los hijos de las cristianas que aquéllos tienen como esposas".

${ }^{97}$ Partida II,29,12.

${ }^{98}$ Partida II,30,3.. 
$\operatorname{ros}^{99}$. Esta obligación corresponde a los parientes más próximos, pero debiendo poseer una serie de cualidades: "seyendo omes de buen recabdo, e sin sospecha, que non ayan cobdicia de su muerte, por razon de heredar los sus bienes; o que ayan sabor que este mucho en captiuo, porque se aprouechen ellos de lo suyo". Si el cautivo no tuviese parientes, entonces el rey o su delegado, nombraría un administrador o administradores para que se encargasen de esos bienes, "de manera que non se pierdan, ni se menoscaben”. El Fuero de Cuenca, por su parte ordena que sea la mujer la encargada de responder por los bienes del marido ${ }^{100}$; en caso de que no tuviese mujer, serían los hijos ${ }^{101}$

Si los parientes encargados de la administración del patrimonio del cautivo cometiesen falsedades con los bienes, no entregando alguno de ellos una vez que fuera liberado o "tomando mas para si de lo que deuiessen", serían castigados por hurto debiendo pagar una indemnización correspondiente al doble del valor del bien o bienes. En el caso de ser un extraño, restituirá la cosa más su valor ${ }^{102}$.

En el momento de la entrega de los bienes del cautivo, tanto a los parientes como a los extraños, se debe realizar un inventario, dándose después a los administradores este documento en presencia de testigos. Además, no sólo deben conservar el patrimonio del cautivo, sino también explotarlo, especialmente si se trata de fincas y parcelas rústicas, pues en caso contrario podrán responder por los daños causados ${ }^{103}$. Finalmente, si no diesen buena cuenta de la administración, "deuen pechar doblado el menoscabo; e demas auer pena, segund fuesse el fecho, por furto, o por fuerça, o por engaño" 104 .

Durante el tiempo que dure el cautiverio, se debe evitar por todos los medios la pérdida de bienes del patrimonio del cautivo, no valiendo las ventas, cambios o donaciones en su perjuicio. Si así se produjese, una vez liberado el cautivo puede recuperar las cosas, teniendo un plazo de cuatro años para demandarlas ante los tribunales, comenzando a contar a partir del tercer día que llegase a su

${ }^{99}$ Partida II,29,4: "Guardados deuen ser mucho todos los bienes de los captiuos, de mientra que ellos en captiuerio fueren, assi que ninguno non gelos tome por fuerça, ni por engaño, ni en ninguna otra manera. Fueras ende, si los tornassen para tomarlos en pro de ellos: ca el que obra de guisa lo fiziesse, deue pechar doblado, lo que dende leuare, sin la pena que ha de auer de forçador, si lo tomo por fuerça, o de engañador, si lo tomo por engaño [...]".

${ }^{100}$ Fuero de Cuenca, capítulo XXIII,16: "Si la mujer del deudor dice que su marido está cautivo o enfermo o muerto, inmediatamente responda en su nombre".

${ }^{101}$ Ibíd., capítulo XXIII,7: "Si el deudor no tiene mujer, pero sí hijos, el demandante tenga con los hijos el pleito que hemos dicho debe tener con la mujer".

102 Partida II,29,4: “[...] Mas si fuessen estraños, deuenlo pechar sencillo, e otro tanto de lo suyo $[\ldots]$...

${ }^{103}$ Ibíd.: "[...] E la manera en que han de rescebir estos bienes, tambien los parientes, como los otros, que lo resciban por escrito, e ante los testigos, nombrando quantas son las cosas que resciben, e quales; porque puedan dar cuenta, e recabdo, quando gelo demandaren, que fizieron dellas. Otrosi deuen fazer adereçar los heredamientos, que fueren rayzes, labrandolos, e aliñandolos, porque ayan ende pro sus dueños. E lo al que fuere mueblo otrosi, poniendolo en recabdo en tal manera, que se aprouechen dello los cuytados, que yazen en captiuo. E los que de otra guisa los dexaren perder, non los aliñando, deuen pechar por otro tanto de lo suyo, quanto fuesse aquello que por su culpa se perdio [...]".

${ }^{104}$ Ibíd. 
casa. Si pasado ese plazo no los demandase, entonces perdería los bienes, a no ser que fuera menor de veinticinco años, pues en ese caso, podrá iniciar las acciones judiciales cuando alcanzase la mayoría de edad, empezando a contar entonces ese término de cuatro años ${ }^{105}$.

Puede suceder que durante el período de cautividad fuese llamado el cautivo a heredar un determinado patrimonio o ser designado legatario de alguno o algunos bienes de una herencia. En este supuesto el fuero de Daroca establece que tiene seis meses de plazo desde que alcanzó la libertad, no desde que se abrió la herencia, para hacerse con los bienes que le correspondan ${ }^{106}$.

Determinados actos jurídicos realizados por el cautivo son nulos de pleno Derecho, como el testamento y el legado, pues el libre se ha convertido en esclavo. Solamente valdrían los realizados antes de la captura, pues gozaba de libertad $^{107}$, pero también durante el período de cautiverio, si se permitiese acudir al lugar donde permanece preso a pariente o a allegados ante quienes pudiese hacer libremente el testamento o legado, y también enviando el cautivo a alguien de confianza ante sus parientes para que vendiesen o empeñasen sus bienes para sacarle del cautiverio, cosa lógica, o para satisfacer sus deudas ${ }^{108}$; sin embargo, "si

${ }^{105}$ Partida II,24,5: “Tiempo, touieron por bien los Antiguos, que non passasse a daño de aquellos que yoguiessen en captiuo, porque perdiessen sus bienes, e los derechos que ouiessen de auer. E por ende ninguno non las puede ganar, mientra ellos assi yoguieren, maguer alguno dellos fuesse tenedor, quanto tiempo quier. Ca si yaziendo en captiuo alguno, non valdria vendida, ni cambio, ni donacion, que fiziessen, a daño de si, segun en este titulo se demuestra; quanto menos deue valer, lo que algunos quisiessen tomar de lo suyo por tiempo. Eporende si el captiuo despues de saliesse de la prision fallasse alguna de sus cosas en poderio de otro, que dixese que la auia ganado por tiempo, bien la podria demandar fasta quatro años, e auerla por derecho. E estos cuatro años se deuen començar a contar, del dia tercero que llegasen a sus casas, fasta en quatro años acabados. Mas si en este tiempo non los demandase, dende en adelante non lo podria fazer con derecho, fueras ende si el captiuo fuesse de menor edad de veynte e cinco años. Ca este atal bien lo puede demandar, e auerlo, fasta que aya edad complida, e despues quatro años. E si en este tiempo non lo demandasse, non lo podria despues fazer: porque se muestra, que lo perdiera por su pereza, o menospreciando su derecho, o non lo sabiendo demandar".

${ }^{106}$ Fuero de Daroca, capítulo 57: "Si alguien debe repartir con otros y está en el reino y, después de la muerte de aquél, por el que debe heredar, en un plazo de medio año no viene a repartir, nadie le responda acerca de la partición; si está cautivo, cuando salga de la cautividad, pero si está en peregrinación, durante un año sea esperado y después no le responda".

${ }^{107}$ Partida II,29,6: “[...] Mas si acaesciesse, que alguno dellos ouiesse fecho mandas, o testamentos, ante que captiuasse, o muriesse despues, yaziendo en captiuo, o si saliesse dende, e non lo reuocasse, o lo mandasse en otra manera, valdria. E esto seria, porque quando lo fizieron eran en su libre pode".

${ }^{108}$ Ibíd.: "Valer non deue testamento, ni manda, que fiziessen los omes, de mientra que yoguieren en captiuo; esto, por quanto yazian en poder de los enemigos, e eran sus sieruos. E porende, testamento, ni manda que fagan, ni otra cosa, non deue valer. Ca si ellos poderio libre oviessen de lo fazer, tantas penas les darian sus Señores, que non establecerian a otros por herederos, si non a los que ellos mandassen. Onde por todas estas razones sobredichas, mandaron los Antiguos, que non valiesse ninguna cosa, que fiziessen, mientras yoguiessen en captiuo. Fuera ende de dos maneras. La vna seria, quando aquellos que los touiessen presos, les quisiessen fazer tanto de amor, que dexassen venir a ellos algunos de sus parientes, o a otros omes, ante quien pudiessen fazer su testamento, o su manda sin ninguna premia. La segunda razon es, quando ellos no pudiessen fazer su testamento libremente, assi como sobredicho es, e embiassen a dezir a sus parientes con alguno, en quien se 
prouado les fuere, que engaño ouiessen fecho en alguna de sus cosas, que fuessen en auer o en heredad, deuenlo pechar doblado, e otro tanto de los suyo. E si non ouiessen de que, deuen morir por ello. E esto porque mostraron cobdicia, e falsedad, en los bienes de aquellos que se fiauan en su lealtad. E otrosi, porque fueron crueles en lo que deuieran ser piadosos" 109 .

Si el cautivo muriese en la prisión, una vez enterados sus herederos de ello, pueden hacerse cargo de su patrimonio, siempre y cuando hubieran hecho todo lo posible para que alcanzase la libertad, pues en caso contrario serían desheredados $^{110}$.

De las garantías patrimoniales que hemos hecho mención no gozarían un determinado tipo de cautivos, aquellos cristianos que sirviesen a príncipes de otra ley y que entrasen en conflicto con sus nuevos señores, aprisionándoles éstos, o que fueran capturados en un combate sostenido contra otros. Tampoco gozarían de garantías aquellos cristianos que, viviendo en tierra de moros sin permiso del rey o de su señor, fueran hechos cautivos por cristianos, pues en este caso, serían vendidos en almoneda, pero solamente a cristianos. A éstos hay que sumar aquéllos que se entregasen voluntariamente a los moros sin luchar y a aquéllos que estando cautivos saliesen momentáneamente de su situación para volver voluntariamente en fecha señalada con la intención de cumplir una determinada misión ${ }^{111}$. Finalmente,

fiassen, como fiziessen dello, vendiendolo, o empeñandolo, para sacar a ellos de captiuo, o para complir sus debdas, o sus mandas. E lo que estos atales fiziessen por su mandado, e en su nome, deue valer tan bien, como si ellos mesmos lo fiziessen [...]”.

${ }^{109}$ Ibíd.

${ }^{110}$ Partida II,29,8: "A menudo acaesce, que mueren los omes yaziendo en captiuo: porende establecieron los Antiguos, que quando sopiessen ciertamente aquello que con derecho han de heredar lo suyo, que dende en adelante pueden vsar de sus bienes, e de sus derechos, tambien como faria el finado, si biuo fuesse, e salido de captiuo. E esto fezieron por derecha razon, ca bien como los herederos son tenudos de pagar las debdas, e las mandas, de aquellos de quien heredaron; asi es derecho, que se aprouechen de sus bienes, e vsen dellos, assi como farian ellos si fuessen biuos. Pero esto se entiende non seyendo en culpa, por dexarlos morir en captiuerio, podiendolos quitar, e non queriendo, assi como diximos en las otras leyes".

${ }^{111}$ Partida II,29, 9: "Departiendose algunos Christianos de sus Señores, o de la tierra donde son naturales, para yr a ayudar omes de otra ley; e morando alla, se desauiniessen con aquellos a quien ayudaban, ansi que los ouiessen de captiuar ellos mismos, o algunos otros, con quien ouiessen guerra; non touieron por bien los Antiguos, que estos atales ouiessen aquelas franquezas, que los otros captiuos sobredichos deuen auer en sus cosas, segun diximos. E si alguna cosa de las suyas se enajenasse por tiempo, estando ellos captiuos, o muriendo alla, non touieron por derecho, que la pudiessen despues cobrar por aquella razon: ante lo deuen perder, tambien como si ellos mismos estuuiessen delante, e las pudiessen demandar, e non quisiessen. Otro tal seria de aquellos, que sin mandado del Rey o de sus Señores, morassen luengamente con los Moros de su grado, maguer non los captiuassen. E aun tanto estrañaron los buenos Christianos antiguos tal fecho como este, que mandaron que si algun Christiano fuesse preso, estando en seruicio de los Moros, aunque non lo touiessen por captiuo, que lo pudiessen vender en almoneda, tambien como si fuesse Moro: solamente que lo vendiessen a Christianos, e non a omes de otra Ley. Otrosi touieron por derecho, que aquellos que se pudiessen defender de los enemigos, e non quisiessen, e se dexassen captiuar; que non ouiessen las franquezas que han los otros captiuos, segun que en estas otras leyes diximos. E esso mismo mandaron de aquellos que sobre su omenaje saliessen de captiuo, para tornar a día señalado, para complir los pleytos que ouiessen puesto con sus Señores, podiendolo fazer, e non quisiesen". 
como dijimos al inicio, agruparíamos aquí a aquellos que aconsejasen en asuntos de guerra o comerciasen con hierro, armas, navíos o maderas para convertirlas en armas o en navíos con los musulmanes ${ }^{112}$.

Si triste es la situación de las personas adultas en cautividad, más lo es cuando se trata de menores, especialmente si nacen dentro de ella. Las Partidas protegen a los hijos nacidos de madres que fueron capturadas mientras se encontraban embarazadas, reconociéndoles el derecho a suceder en los bienes de su padre o de su madre y de otros derechos que les correspondan cuando recuperen la libertad ${ }^{113}$. El mismo derecho se reconoce a los hijos concebidos y nacidos dentro del cautiverio de los padres, si éstos han convivido juntos durante ese duro período ${ }^{114}$.

Si el hijo retornase del cautiverio con uno de sus progenitores, continuando el otro en prisión, el ordenamiento jurídico le considera heredero de los bienes del padre o madre que ha sido liberado; pero con respecto al progenitor cautivo no se le reconoce ningún derecho hasta que éste sea liberado y le reconozca como suyo, pues "touieron por bien los Antiguos, que pudiesse el fijo heredar en los bienes de su padre. E esto seria, quando acaesciesse, que el que yoguiesse en captiuo fuesse desfuziado, que le non querian dende sacar aquellos que eran tenudos de lo fazer, e el con cuyta de salir de aquella prision, ouiesse fijo de alguna muger de aquella Ley, que le prometiesse de sacarlo della, si despues desta promesa lo sacasse, e saliesse ella con el, e el fijo, o la fija con la madre, o sin ella; si aquel que salio de la prision, seyendo en su poder, lo conosciesse por fijo, o por fija, e lo tornasse a su Ley, e mostrasse que sus herederos non lo quisieron sacar de captiuo, podiendolo fazer, e que por razon de aquel, saliera del, estonce aquel deue heredar sus bienes, e non los otros" ${ }^{115}$.

También tienen protección jurídica los antiguos dueños de aquellos lugares y bienes que han sido recuperados del enemigo. Las Partidas distinguen entre dominios o "señoríos" mayores (que según Gregorio López se trataba de ducados, condados y marquesados) y el resto. En el primer caso, pasan íntegramente a su antiguo dueño, mientras que en el segundo, si en cuatro años no se demanda su recuperación se harán propiedad el que los ha reconquistado, plazo que no comenzará a contar si el dueño es menor de 25 años, esperándose a que alcance dicha edad. También se aplicará esta misma excepción en el caso de recuperarse parte del territorio perteneciente a una población y el señor de ésta no diera permiso a las autoridades municipales a solicitar la devolución; deberán esperar al consentimiento señorial, contando a partir de entonces el plazo de cuatro años ${ }^{116}$.

${ }^{112}$ Ver notas 5 y 6.

${ }^{113}$ Partida II,29,7: "Preñada seyendo alguna muger, quando la captiuassen, maguer pariesse en tierra de los enemigos, quando quier que saliese de poder dellos el fijo, o la fija, que alla nasciesse, deue ser recebido en los bienes quel pertenesciessen de su padre, o de su madre, e auer en saluo su derecho en todas las cosas, bien assi como si fuesse nascido en la su casa dellos [...]".

${ }^{114}$ Ibíd.: "[...] Mas si por ventura acaesciesse, que captiuassen marido e muger en vno, e yaziendo en captiuo se empreñasse de su marido, si despues de esso saliessen de poder de los enemigos, amos de so vno, e el fijo, o fija con ellos; deue auer su derecho en todas cosas, tambien como si fuesse engendrado, o nascido en tierra de Christianos [...]".

${ }^{115}$ Ibíd.

${ }^{116}$ Partida II,29,10: "Imperios, Reynos, e otras tierras, caen muchas vegadas en poder de los enemigos, perdiendolos aquellos que dende son naturales, e viniendo en mano de otros estraños que 
[Recibido el 11 y aprobado el 28 de agosto de 2010].

\section{BIBLIOGRAFÍA}

Codex Iustinianus, en Corpus Iuris Civilis (Berlin, 1906).

Decretalium Collectiones, en Corpus Iuris Canonici (Graz, 1955).

Decretum Magistri Gratiani, en Corpus iuris canonici (Graz, 1955).

Díaz GonzÁlez, Francisco Javier, La base jurídica romana en la regulación del cautivo en las Partidas, en Revista General de Derecho Romano, 14 (2010).

Espéculo [ed. de la Real Academia de la Historia (Madrid, 1836)].

Fuero de Alba de Tormes [ed de P. Carrasco - I. Carrasco, Estudio léxico-semántico de los fueros leoneses de Zamora, Salamanca, Ledesma y Alba de Tormes. Concordancias lematizadas (Granada, 1997)), dos volúmenes].

Fuero de Calatayud [ed. de J. I. Algora Hernando y F. Arranz Sacristán (Zaragoza, 1982)].

Fuero de Cuenca [ed. de A. Valmaña Vicente (Cuenca, 1978)].

Fuero de Daroca [ed. de M. del M. Agudo Romeo (Zaragoza, 1992)].

Fuero de Escalona [ed. de A. García-Gallo, Los Fueros de Toledo, en Anuario de Historia del Derecho Español, 45 (1975)].

Fuero de Guadalajara de 1133, en Muñoz y Romero, T., Colección de Fueros Municipales y Cartas Pueblas de los reinos de Castilla, León, Corona de Aragón y Navarra (Madrid, 1847).

Fuero de las Cabalgadas, en Memorial Histórico Español (Madrid, 1851), II.

Fuero de Plasencia [ed. de M. J. Postigo Aldeamil, en Revista de Filología Románica, 2 (1984)].

Fuero de Teruel (ed. de Max Gorosch (Estocolmo, 1950)).

Fuero de Viguera y Val de Funes (ed. de J. M. Ramos y Loscertales (Salamanca, 1956)).

Fuero romanceado de Sepúlveda [en Los Fueros de Sepúlveda, ed. de E. Sáez (Segovia, 1953)].

cambian los nomes de los logares, e departen los terminos, e vsan de los derechos, de otra manera que ante eran; e despues acaesce, que a tiempo tornan en poder de aquellos cuyos fueron primero: e porende los Antiguos llamaron captiuos aquellos logares, en quanto eran desapoderados dellos, aquellos cuyos solian ser por derecho. E touieron por derecho, que despues que los cobrassen, $e$ saliessen de aquel captiuerio, que fuessen tornados al primer estado derechamente, assi como ante estauan. E si quisiessen, que pudiessen demandar el Señorio, e todos sus terminos, e los otros derechos, e cobrarlos como de primero los auian. E que ningun tiempo non pasasse contra ellos, por fazerles perder su derecho. E esto se entiende de los Señorios mayores, porque no mengüassen, nin se desfiziessen del todo. Mas de los menores, si despues que los ouiessen cobrado aquellos cuyos deuen ser, fasta quatro años, non quisiessen a aquellos sus logares, puedenlos perder por tiempo; fueras ende si aquel, que lo ouiesse a demandar non fuesse de edad, ca este en quanto non lo fuesse, e aun despues fasta en quatro años, en saluo finca su derecho, para demandarlo si quisiere. E esso mismo dezimos si alguna Cibdad, o Villa, o otro Logar, que fuesse perdido e cobrado, assi como diximos, quisieren demandar sus terminos, o sus derechos fasta quatro años, e su Señor non gelo consintiesse: ca mientra el Señor non quisiesse, non lo puede fazer, nin correria tiempo contra ellos, pues que por fuerça de mandamiento lo ouiessen dexado. Mas despues quando al Señor ploguiesse, bien lo podrian demandar". 
Fueros de Aragón [ed. de A. Gargallo Moya (Zaragoza, 1992)].

Fueros de Aragón (ed. de G. Tilander, 1937).

Furs de Valencia [ed. de G. Colón y A. García (Barcelona, 1980-1999)].

Las siete partidas del Sabio Rey don Alonso el Nono; nuevamente glosadas por Gregorio López (Madrid, BOE, 1973).

Los Usatges de Barcelona [ed. de F. Valls Taberner (Barcelona, 1984)].

Vidal Mayor [ed. de G. Tilander (Lund, 1956)]. 